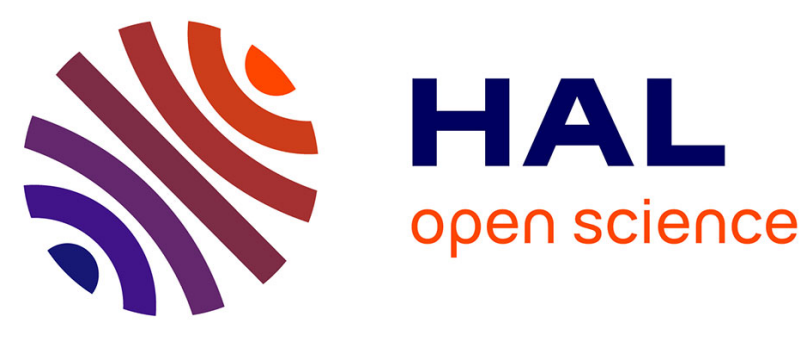

\title{
Limited Zn and Ni mobility during simulated iron formation diagenesis
}

Leslie J. Robbins, Elizabeth D. Swanner, Stefan Lalonde, Merle Eickhoff, Megan L. Paranich, Christopher T. Reinhard, Caroline L. Peacock, Andreas Kappler, Kurt O. Konhauser

\section{To cite this version:}

Leslie J. Robbins, Elizabeth D. Swanner, Stefan Lalonde, Merle Eickhoff, Megan L. Paranich, et al.. Limited Zn and Ni mobility during simulated iron formation diagenesis. Chemical Geology, 2015, 402, pp.30-39. 10.1016/j.chemgeo.2015.02.037 . insu-01164191

\section{HAL Id: insu-01164191 https://hal-insu.archives-ouvertes.fr/insu-01164191}

Submitted on 8 Mar 2021

HAL is a multi-disciplinary open access archive for the deposit and dissemination of scientific research documents, whether they are published or not. The documents may come from teaching and research institutions in France or abroad, or from public or private research centers.
L'archive ouverte pluridisciplinaire HAL, est destinée au dépôt et à la diffusion de documents scientifiques de niveau recherche, publiés ou non, émanant des établissements d'enseignement et de recherche français ou étrangers, des laboratoires publics ou privés. 


\section{UNIVERSITY OF LEEDS}

This is a repository copy of Limited Zn and Ni mobility during simulated iron formation diagenesis.

White Rose Research Online URL for this paper:

http://eprints.whiterose.ac.uk/86170/

Version: Accepted Version

\section{Article:}

Robbins, LJ, Swanner, ED, Lalonde, SV et al. (6 more authors) (2015) Limited Zn and Ni mobility during simulated iron formation diagenesis. Chemical Geology, 402. 30 - 39. ISSN 0009-2541

https://doi.org/10.1016/j.chemgeo.2015.02.037

(c) 2015, Elsevier. Licensed under the Creative Commons Attribution-NonCommercial-NoDerivatives 4.0 International http://creativecommons.org/licenses/by-nc-nd/4.0/

\section{Reuse}

Unless indicated otherwise, fulltext items are protected by copyright with all rights reserved. The copyright exception in section 29 of the Copyright, Designs and Patents Act 1988 allows the making of a single copy solely for the purpose of non-commercial research or private study within the limits of fair dealing. The publisher or other rights-holder may allow further reproduction and re-use of this version - refer to the White Rose Research Online record for this item. Where records identify the publisher as the copyright holder, users can verify any specific terms of use on the publisher's website.

\section{Takedown}

If you consider content in White Rose Research Online to be in breach of UK law, please notify us by emailing eprints@whiterose.ac.uk including the URL of the record and the reason for the withdrawal request. 


\section{Limited $\mathrm{Zn}$ and Ni mobility during simulated iron}

\section{formation diagenesis}

\section{Leslie J. Robbins ${ }^{a^{*}}$, Elizabeth D. Swanner ${ }^{b}$, Stefan V. Lalonde ${ }^{c}$, Merle Eickhoff ${ }^{\text {b }}$,}

Megan L. Paranich ${ }^{\mathrm{a}}$, Christopher T. Reinhard ${ }^{\mathrm{d}}$, Caroline L. Peacock ${ }^{\mathrm{e}}$, Andreas

Kappler $^{\text {b }}$, and Kurt O. Konhauser ${ }^{a}$

${ }^{a}$ Department of Earth and Atmospheric Sciences, University of Alberta, 1-26 Earth

Sciences Building, University of Alberta, Edmonton, Alberta, T6G $2 E 3$ Canada

${ }^{b}$ Geomicrobiology Group, Center for Applied Geosciences, University of Tübingen,

Sigwartstraße 10, D-72076 Tübingen, Germany

${ }^{c}$ European Institute for Marine Studies, Technopôle Brest-Iroise, UMR 6538, Domaines

Océaniques, 29280 Plouzané, France

${ }^{d}$ School of Earth and Atmospheric Sciences, Georgia Institute of Technology, 311 Ferst

Drive Atlanta, Georgia, 30332, USA

${ }^{e}$ School of Earth and Environment, University of Leeds, Earth and Environment Building, Leeds, LS2 9JT, United Kingdom

Citation: Robbins, L.J., Swanner, E.D., Lalonde, S.V., Eickhoff, M., Paranich, M.L.,

Reinhard, C.T., Peacock, C.L., Kappler, A., and Konhauser, K.O. (2015) Limited Zn and

Ni mobility during simulated iron formation diagenesis. Chemical Geology 402: 30-39.

Doi: http://dx.doi.org/10.1016/j.chemgeo.2015.02.037

(C) 2015, Robbins. Licensed under the Creative Commons Attribution-NonCommercial-NoDerivatives 4.0 International http://creativecommons.org/licenses/by-nc-nd/4.0/ 


\begin{abstract}
Iron formations (IF) are iron- and silica-rich chemical precipitates that were deposited during the Precambrian. Several recent studies have demonstrated how the trace metal abundances in IF can be used as proxies for the bioavailability of trace metals in ancient seawater; with the ultimate goal being to understand first-order controls on the composition of the ancient biosphere. However, the utility of IF as proxies depends on the immobilization of trace metals during diagenesis. Here, we assess the mobility of $\mathrm{Zn}$ and $\mathrm{Ni}$ from ferric oxyhydroxides (ferrihydrite) in the absence and presence of organic matter (glucose) during simulated diagenesis $\left(170^{\circ} \mathrm{C}, 1.2 \mathrm{kbar}\right)$; similar to what some Precambrian IF experienced. Quantitative concentration data, coupled with x-ray diffraction analysis and electron microprobe element mapping, demonstrate that both metals are relatively immobile during simulated diagenesis. Additionally, the mechanism for initial Ni sorption is examined using x-ray adsorption spectroscopy. For the initial sorption of trace elements in abiotic ferrihydrite experiments, $93.38 \% \mathrm{Zn}$ and $65.95 \% \mathrm{Ni}$ were initially sorbed. In experiments utilizing biogenic ferrihydrite, $97.03 \%$ of $\mathrm{Zn}$ and $93.38 \%$ of $\mathrm{Ni}$ were initially sorbed. Following the diagenetic capsule treatments, more than $99 \%$ of $\mathrm{Zn}$ and more than $91.9 \%$ of $\mathrm{Ni}$ were retained under the varied conditions considered here. Capsule experiments suggest the strong retention of $\mathrm{Zn}$ and $\mathrm{Ni}$ following the diagenesis of either abiotic or biogenic ferrihydrite. Overall, our results indicate that paleomarine $\mathrm{Zn}$ and $\mathrm{Ni}$ concentrations are likely to be faithfully recorded in wellpreserved IF deposits.
\end{abstract}


Keywords: iron formations; Precambrian; zinc; nickel; diagenesis; iron oxyhydroxides; trace metal mobility; X-ray Absorption Spectroscopy

\section{Introduction}

Iron formations (IF) are a key sedimentary proxy record for tracking the chemical history of seawater and reconstructing trace metal abundances in the Precambrian oceans. Many trace metals, such as zinc $(\mathrm{Zn})$ and nickel $(\mathrm{Ni})$, are critical components of a variety of eukaryotic and prokaryotic metalloenzymes, respectively (Williams and da Silva, 1996). As a result, reconstructing their concentrations in ancient seawater may provide crucial information about the constraints imposed on the evolving early biosphere (e.g., Dupont et al., 2010).

Iron formations contain iron $(\mathrm{Fe})$ minerals with various oxidation states, such as hematite $\left(\mathrm{Fe}_{2} \mathrm{O}_{3}\right)$, magnetite $\left(\mathrm{Fe}_{3} \mathrm{O}_{4}\right)$ and siderite $\left(\mathrm{FeCO}_{3}\right)$, often in a cherty matrix. Additionally, some IF may contain significant Fe(II)- and/or Fe(III)-silicates, such as greenalite, stilpnomelane, minnesotaite, chamosite, riebeckite, and ferri-annite (Klein, 2005). It is important to note, however, that these are all secondary minerals, and that the primary iron precipitates probably comprised ferric oxyhydroxides, such as ferrihydrite $\left(\mathrm{Fe}(\mathrm{OH})_{3}\right)$ (see Bekker et al., 2010 for review). Although the actual mechanisms of $\mathrm{Fe}(\mathrm{II})$ oxidation remain uncertain, they appear to have been biologically mediated (e.g., Posth et al., 2013a, 2014; Pecoits et al., 2015). The organic biomass deposited with $\mathrm{Fe}(\mathrm{OH})_{3}$ would subsequently serve as a reductant during diagenesis and metamorphism (e.g., Perry et al., 1973; Konhauser et al., 2005; Johnson et al., 2008; Craddock and Dauphas, 2011). Fe(III) reduction by organic matter is indicated by (i) the presence of ferrous iron- 
containing minerals, such as magnetite $\left(\mathrm{Fe}_{3} \mathrm{O}_{4}\right)$ and siderite $\left(\mathrm{FeCO}_{3}\right)$, (ii) the low organic carbon content of IF today $(<0.5 \%$; Gole and Klein, 1981), and (iii) $\mathrm{Fe}, \mathrm{C}$ and $\mathrm{O}$ isotope compositions in Fe-carbonates associated with IF (Johnson et al., 2008; Heimann et al., 2010; Craddock and Dauphas, 2011). In addition to Fe(III) reduction coupled to organic carbon oxidation (i.e., anaerobic chemoheterotrophy), when a solution containing ferrous iron $(\mathrm{Fe}(\mathrm{II}))$ is present, redox-driven recrystallization of the primary $\mathrm{Fe}(\mathrm{OH})_{3}$ minerals may cause loss of Ni to solution (Frierdich et al., 2011). Therefore, constraining the mobility of elements, such and $\mathrm{Zn}$ and $\mathrm{Ni}$, under realistic diagenetic scenarios is critical for our interpretation of the IF record, and the implications for paleomarine systems which are drawn from it.

There are indications from Archean IF that Ni and Zn may relatively enriched, and therefore, available as key nutrients on the early Earth. These include relatively high $\mathrm{Ni}$ and $\mathrm{Zn}$ concentrations found in the $3.75 \mathrm{Ga}$ Nuvvuagittiq IF, Canada (Mloszewska et al., 2012) and $\mathrm{Ni}$ enrichments considered to be primary in origin in the IF of the Mesoarchean Witwatersrand Supergroup in South Africa (Smith et al., 2013). Furthermore, compilations of both $\mathrm{Ni}$ and $\mathrm{Zn}$ in the IF record have recently been presented (Konhauser et al., 2009; Robbins et al., 2013), as well as for $\mathrm{Zn}$ in the shale record (Scott et al., 2013). Distribution coefficients $\left(\mathrm{K}_{\mathrm{D}}\right)$ between seawater and $\mathrm{Fe}(\mathrm{OH})_{3}$ have been applied to the IF record to extrapolate paleomarine $\mathrm{Ni}$ and $\mathrm{Zn}$ concentrations (Konhauser et al., 2009; Robbins et al., 2013). These studies have shown dissimilar temporal trends throughout the Precambrian, with seawater Ni concentrations appearing to have decreased rapidly from $\sim 400$ to $100 \mathrm{nM}$ between 2.7 and $2.5 \mathrm{Ga}$ (Konhauser et al., 2009). The IF record for $\mathrm{Ni}$ indicates a sudden, dramatic decrease in marine Ni levels 
immediately prior to the Great Oxidation Event (GOE) (Konhauser et al., 2009). This crash in Ni may have been a contributing factor leading to the GOE and had significant implications for the biosphere $\sim 2.7 \mathrm{Ga}$. However, the marine $\mathrm{Zn}$ reservoir appears to have remained constant with an estimated seawater concentration of $\sim 10 \mathrm{nM}$ (Robbins et al., 2013). When taken together, the IF and shale records for $\mathrm{Zn}$ through time effectively and independently point to near modern levels of marine $\mathrm{Zn}$ from the Archean through to the modern (Robbins et al., 2013; Scott et al., 2013). This is in contradiction to previous estimates based on thermodynamic models (e.g., Saito et al., 2003) and the idea that $\mathrm{Zn}$ would have been biolimiting to early eukarytoes and delayed their diversification (Dupont et al., 2010). Accordingly, studying the IF record provides a key window into evaluating paleomarine conditions, especially with regards to trace metal abundances. As such, understanding the potential diagenetic impacts is critical to such evaluations.

However, the extent to which $\mathrm{Zn}$ and $\mathrm{Ni}$ are mobilized when the precursor ferrihydrite underwent reduction and dehydration during diagenesis remains unclear. Our work builds on methodologies of previous simulated IF diagenesis experiments that focused on Fe-mineral transformations (Posth et al., 2013b; Köhler et al., 2013), in order to evaluate trace element mobilization during diagenesis and the robustness of previous paleomarine $\mathrm{Zn}$ and Ni estimates. Additionally, due to the role of organic matter as a diagenetic reductant, we consider reactions between organic carbon and $\mathrm{Fe}(\mathrm{III})$ in our diagenetic experiments; with $\mathrm{Zn}$ or Ni sorbed to either synthetic 2-line ferrihydrite with added glucose in the capsule or sorbed directly to biogenic ferrihydrite. We couple these results with micro X-ray diffraction $(\mu \mathrm{XRD})$ analysis of the post-diagenetic mineralogy 
for selected samples and electron microprobe mapping (EMPA) of $\mathrm{Zn}$ and $\mathrm{Ni}$ to examine diagenetic trace element redistribution.

\section{Methods}

\subsection{Simulated diagenesis experiments}

Diagenetic capsule experiments on synthetic Fe oxyhydroxide precipitates (Posth et al., 2013b) demonstrate that the Fe mineralogy observed in IF today can be reproduced after incubation of synthetic 2-line ferrihydrite in the presence or absence of glucose (as a proxy for biomass). Capsules were subjected for 14 days at $170^{\circ} \mathrm{C}$ and $1.2 \mathrm{kbar}$, approximately the diagenetic pressure and temperature (P-T) conditions of one of the largest and most studied iron formations on Earth, the Transvaal Supergroup BIF (Miyano and Klein, 1984; Miyano, 1987). Furthermore, these conditions mimic previous diagenetic capsule experiments (Posth et al., 2013b; Köhler et al., 2013), and therefore, facilitate a ready comparison between experimental conditions. Our experimental duration and P-T parameters are obviously much abbreviated compared to natural burial diagenesis and metamorphism that takes thousands to millions of years; and are less than experienced by some IF which were subjected to amphibolite facies. However, we still effectively capture the crucial step of the transformation of $\mathrm{Fe}(\mathrm{OH})_{3}$ to the minerals typically observed in IF, i.e., hematite $\left(\mathrm{Fe}_{2} \mathrm{O}_{3}\right)$, some of which is thought to have occurred during early diagenesis at temperatures below $140^{\circ} \mathrm{C}$ (Becker and Clayton, 1976).

Diagenetic experiments and analysis were performed at the University of Tübingen using similar procedures and apparatus as per Posth et al. (2013b). Our experiments consider diagenetic mobilization of $\mathrm{Zn}$ and $\mathrm{Ni}$ from (1) 2-line ferrihydrite 
(Fh), as a proxy for primary Fe-oxyhydroxides formed from the chemical oxidation of $\mathrm{Fe}(\mathrm{II})$ with $\mathrm{O}_{2}$, and (2) biogenic ferrihydrite (BF) precipitated by a marine, $\mathrm{Fe}(\mathrm{II})$ oxidizing phototrophic bacterial culture (Rhodovulum iodosum, see Wu et al., 2014; Eickhoff et al., 2014). We utilize the BF as a proxy for primary Fe-oxyhydroxides formed by $\mathrm{Fe}(\mathrm{II})$-oxidizing bacteria. Our experiments consisted of three general steps: (i) the synthesis of $\mathrm{Fh}$, either as abiotic or cell-mineral aggregates, and sorption of $\mathrm{Ni}$ and $\mathrm{Zn}$, (ii) treatment of the trace element sorbed minerals, with or without organic material, under simulated diagenetic P-T conditions, and (iii) quantification of the concentration of Ni and Zn mobilized.

Capsules were named according to a consistent scheme, i.e. ZnFh-1, where $\mathrm{Zn}$ or Ni refers to the trace element sorbed, and Fh or BF indicates abiotic 2-line ferrihydrite or the biogenic cell-mineral aggregates, respectively. The numbers refer to the experimental replicates, where for the abiotic Fh experiments, replicates 1 and 2 contained glucose added as an organic carbon source, and replicates 3 and 4 lacked glucose. In experiments with $\mathrm{BF}$, no glucose was added because cell material served as a source of organic carbon. In these samples, the numbers only serve to identify the respective capsule among replicates. For example, NiFh-1 indicates a capsule containing Ni sorbed to Fh with glucose, while ZnBF3 indicates Zn sorbed to BF. Capsules ZnFh-1, NiFh-3 and ZnBF1 were excluded from further analysis as the integrity of the seals were compromised during diagenetic treatments. Finally, the prefix C- denotes a control capsule (e.g., CZnFh1). Control capsules were set up to mirror experimental capsules but were stored in the dark in Eppendorf tubes and subjected to room temperature and pressure for the same period of time as experimental capsules. 


\subsubsection{Synthesis of ferrihydrite and sorption of $\mathrm{Zn}$ or $\mathrm{Ni}$}

Synthetic Fh used in abiotic experiments was prepared via methods previously described (c.f. Cornell and Schwertmann, 2003) and freeze-dried prior to sorption of Ni or Zn. The marine photoferrotroph, Rhodovulum iodosum, was cultivated in artificial seawater medium as described by Wu et al. (2014); the phosphate content was reduced to $1 \mathrm{mM}$ to minimize $\mathrm{FePO}_{4}$ precipitation, with additional $\mathrm{NaCl}$ added to maintain the same ionic strength as per Eickhoff (2013). $\mathrm{FeCl}_{2}$ was added to a concentration of $10 \mathrm{mM}$, but the medium was not filtered to remove initial $\mathrm{Fe}$ carbonate and $\mathrm{Fe}$ phosphate that precipitated. The strain was then inoculated and grown at $12.82 \mu \mathrm{mol}$ photons $/ \mathrm{m}^{2} / \mathrm{s}^{2}$ until all $\mathrm{Fe}^{2+}$ was oxidized, as determined by the Ferrozine assay (Stookey, 1970). The cellmineral aggregates were then collected by centrifugation and washed four times with the growth medium lacking bicarbonate buffer and harvested by centrifugation at $4000 \mathrm{rpm}$ for 10 minutes before freeze-drying.

Sorption of $\mathrm{Zn}$ and $\mathrm{Ni}$ to both $\mathrm{Fh}$ and $\mathrm{BF}$ was accomplished by introducing $\sim 50$ $\mu \mathrm{M}$ of $\mathrm{Zn}$ or Ni (from Merck ICP-MS standards) in the presence of $1 \mathrm{~g} / \mathrm{L}$ Fh or BF in solution prepared to seawater ionic strength with $0.5 \mathrm{M} \mathrm{NaNO}_{3}$ and buffered by $0.1 \mathrm{M}$ $\mathrm{H}_{3} \mathrm{BO}_{3}$ to a $\mathrm{pH}$ value of 8 . Sorption occurred over a 24-hour period, before the solution was passed through a $0.2 \mu \mathrm{M}$ Millipore filter, and the solid particles were recovered. Filtrates were analyzed for $\mathrm{Zn}$ and $\mathrm{Ni}$ by Inductively Coupled Plasma Optical Emission Spectroscopy (ICP-OES), on a Perkin Elmer Optima 5300 at the University of Tübingen, to determine the amount of $\mathrm{Zn}$ or Ni lost due to sorption. For ICP-OES measurements, the percent relative standard deviation (\%RSD) was better than $\pm 8 \%$ and $\pm 5 \%$ for $\mathrm{Zn}$ and 
$\mathrm{Ni}$, respectively. Calculations of the amount of $\mathrm{Zn}$ and $\mathrm{Ni}$ added normalized to the weight of solid particles, as well as the percentage of $\mathrm{Zn}$ or Ni sorbed, are provided in Table 1. In all cases the majority of $\mathrm{Zn}$ and $\mathrm{Ni}$ was sorbed. Solid particles were then air-dried at room temperature prior to being loaded in experimental gold capsules.

\subsubsection{Mobilization experiments}

Three experiments were conducted with $\mathrm{Zn}$ and Ni sorbed independently to: (1) Fh only, (2) Fh with added glucose, and (3) BF. Experiments followed the protocols of Posth et al. (2013b) in which Fh is transformed to hematite via dry heating. Experimental gold capsules with Fh were set-up such that $100 \mathrm{mg}$ of ferrihydrite with $\mathrm{Zn}$ or Ni sorbed was loaded into the capsules. For capsules with Fh and glucose, $4 \mathrm{mg}$ of glucose were physically mixed with the Fh to achieve a ratio of electron reducing equivalents of $\sim 0.6$ that could be transferred from glucose to Fh during diagenetic treatment (as per Posth et al., 2013b). This approximates the low organic carbon content of IF, which would limit the number of electrons available for diagenetic Fe(III) reduction (Konhauser et al., 2005). Capsules with BF contained approximately $35 \mathrm{mg}$ of BF cell-mineral aggregate. Gold capsules were crimped closed and then sealed using an arc welder. During welding the capsule remained cool to the touch, precluding any temperature reaction prior to capsule incubation. The capsules were weighed before and after a sonication treatment in a water bath to ensure that the contents were sealed. Capsules were then incubated at $170^{\circ} \mathrm{C}$ and $1.2 \mathrm{kbar}$ for 14 days in a high-pressure autoclave (Sitec Sieber Engineering Ag, Zürich, Switzerland). In tandem with experimental capsules, control capsules were 
incubated at room temperature for 14 days to account for any reactions under ambient conditions.

\subsubsection{Quantification of Zn or Ni mobilized}

Following incubation, capsule exteriors were cleaned with acetone, and then capsules were cut into smaller sections and placed into Falcon tubes. To each Falcon tube $5 \mathrm{~mL}$ of pH-buffered seawater ionic strength solution $\left(0.5 \mathrm{M} \mathrm{NaNO}_{3}\right.$ and $0.1 \mathrm{M} \mathrm{H}_{3} \mathrm{BO}_{3}, \mathrm{pH}$ 8) was added and then the capsules were sonicated for 30 minutes. The solution was then removed and the sonication repeated with fresh solutions. Filters for selected samples were retained for subsequent analysis by $\mu \mathrm{XRD}$ and EMPA, following an 18-month period of oxidation (see section 2.3).

The combined rinse solutions for each sample were filtered $(0.22 \mu \mathrm{M}$ Millipore filters), acidified (with trace metal grade $\mathrm{HNO}_{3}$ to a final concentration of 1-2\%) and then diluted prior to ICP-OES analysis. The purpose of this step was to rinse the postdiagenetic particles in a solution that resembled seawater (ionic strength, $\mathrm{pH}$ ) in order to recover any $\mathrm{Zn}$ or $\mathrm{Ni}$ mobilized during diagenetic reactions. This allowed for the recovery of the resultant diagenetic waters (i.e., to collect the overpressure liquid produced by the dehydration of $\mathrm{Fh}$ to hematite), without leaching immobilized $\mathrm{Zn}$ or $\mathrm{Ni}$ from the particles (i.e., $\mathrm{Zn}$ or Ni strongly bound to hematite). Additionally, we consider that porewaters would have likely remained circumneutral - although some $\mathrm{CO}_{2}$ would have been released during organic mineralization, any anaerobic respiration, as would be realistic for Archean sedimentary systems, would have led to an increase in $\mathrm{pH}$ (c.f. Konhauser, 2007). $\mathrm{Zn}$ or Ni concentrations were used to determine the percentage of 
initially sorbed $\mathrm{Zn}$ or $\mathrm{Ni}$ to $\mathrm{Fh}$ or $\mathrm{BF}$ that was retained by the minerals in each capsule (Table 2). Errors on the percentage of metal retained (Table 2) were calculated using the two-sigma level ICP-OES analysis standard deviations (\%RSD was better than $\pm 8 \%$ for $\mathrm{Zn}$ and $\pm 5 \%$ for $\mathrm{Ni}$, when the analyte was above detection limits). The percent error in the trace metal retained $\left( \pm 2 \sigma \mathrm{TM}_{\text {retained }}(\%)\right)$ is equal to the absolute value of the maximum variation from the trace metal retained, relative to the initial trace metal in the capsule (equation 1). Where $\mathrm{TM}_{\text {capsule }}$ is the initial amount of $\mathrm{Zn}$ or $\mathrm{Ni}$ in each capsule, $\mathrm{TM}_{\text {released }}$ is the amount of $\mathrm{Zn}$ or Ni released and $2 \sigma$ is the variation in ICP-OES measurements.

$$
\pm 2 \sigma \mathrm{TM}_{\text {retained }}(\%)=\left|\left(\left(\mathrm{TM}_{\text {capsule }}-\mathrm{TM}_{\text {released }} \pm 2 \sigma\right) / \mathrm{TM}_{\text {capsule }}\right)-1\right| \mathrm{x} 100
$$

\subsubsection{Calculation of C:Fe ratios}

Molar ratios of C:Fe were calculated for each sample containing organic matter. For capsules with Fh we utilized an ideal formula of $\mathrm{Fe}(\mathrm{OH})_{3}$, molar mass $=106.87 \mathrm{~g} / \mathrm{mol}$ and glucose $(180.15 \mathrm{~g} / \mathrm{mol})$. This allowed for the determination of the moles of glucose based on the percentage of the molecular weight that carbon accounts for in glucose and the mass of glucose added (see equation 2). In equation 2, $m$ is the mass in grams added to the capsule, and the ratio of 72.06 to 180.15 represents the molar mass of carbon in

glucose to the total molar mass. The calculated moles of carbon added as glucose were then normalized to the moles of $\mathrm{Fe}$ in the ferrihydrite added (equation 3).

$$
\begin{aligned}
& \operatorname{mol~C}=\left(m_{\text {glucose }} *(72.06 / 180.15)\right) /(12.01 \mathrm{~g} / \mathrm{mol}) \\
& \operatorname{mol~Fe}=\left(m_{\text {Fe-particles }} *(55.85 / 106.87)\right) /(55.85 \mathrm{~g} / \mathrm{mol})
\end{aligned}
$$


For experiments with BF the total carbon content was measured using an Elementar Vario EL at the University of Tübingen. Total inorganic carbon was not determined because the acid treatment required would have dissolved some of the BF as well. Inorganic carbon was present in the growth medium as $\mathrm{NaHCO}_{3}$ buffer in equilibrium with $\mathrm{N}_{2} / \mathrm{CO}_{2}$ gas. However, the cell-mineral aggregates were washed four times in a basal medium without bicarbonate (see above for description) prior to freezedrying and this should have removed any inorganic carbon in solution. The moles of carbon were calculated by equation 4 and normalized to the moles of $\mathrm{Fe}$ in the $\mathrm{BF}$ added to each capsule as calculated in equation 5. For the BF, the cell-mineral aggregates are a combination of $\mathrm{Fe}(\mathrm{OH})_{3}$ and organic carbon $\left(\mathrm{CH}_{2} \mathrm{O}\right)$ and these exist in a 4:1 molar ratio, resulting in a cell mineral aggregate molar mass of $\sim 458 \mathrm{~g} / \mathrm{mol}$. A $5 \%$ variation in the molar mass of the cell-mineral aggregates would result in a corresponding $\pm 5 \%$ change in the molar $\mathrm{C}$ to $\mathrm{Fe}$ ratios for the $\mathrm{BF}$.

$$
\begin{gathered}
\operatorname{mol~C}=\left(\left(\% C_{\text {organic }} / 100\right) * m_{B F}\right) /(12.01 \mathrm{~g} / \mathrm{mol}) \\
\mathrm{mol} \mathrm{Fe}=\left(m_{B F} *((4 * 55.85) / 458)\right) /(55.85 \mathrm{~g} / \mathrm{mol})
\end{gathered}
$$

The average molar $\mathrm{C}$ :Fe ratio for capsules with $\mathrm{Fh}$ and glucose was determined to be $\sim 0.1446 \pm 0.0008$, which is close to that for capsules with BF measured as $\sim 0.1792$ (Table 2).

\subsection{X-ray Absorption Spectroscopy}

X-ray absorption spectroscopy (XAS) of the initial Ni-sorbed Fh sample was collected at the Ni K-edge $(8.333 \mathrm{keV})$ at the Diamond Light Source in the UK. During data 
collection, storage ring energy was $3.0 \mathrm{GeV}$ and the beam current was approximately 200 $\mathrm{mA}$. The sample was presented to the X-ray beam as a thick paste held in a Teflon slide and sealed either side of the sample slot with Kapton tape. XAS data were collected from 16 scans in fluorescence mode using a Ge 9-element detector. A series of test scans were performed prior to data collection to confirm that there was no photo-redox or visible drying of the sample during data collection. Energy calibration was achieved by assigning the first inflection point of $\mathrm{Au}(\mathrm{L} 3)$ to $11.919 \mathrm{keV}$.

XAS data reduction was performed using ATHENA (Ravel and Newville, 2005) and the spectrum was fit using DL_EXCURV (Tomić et al., 2005). The spectrum was fit in k-space over $3-12 \AA^{-1}$, with no Fourier filtering during data analysis, and the fitting included full multiple scattering as coded in EXCURV98 (Binsted, 1998). Multiple scattering calculations require specification of the full three dimensional structure of the Ni coordination environment (i.e., bond angles in addition to bond lengths). This was done using hypothetical model clusters with $\mathrm{C} 1$ symmetry, for various different $\mathrm{Ni}$ surface complexation coordination geometries (including mononuclear monodenatate, mononuclear bidentate edge-sharing and mononuclear bidentate corner-sharing).

The number of independent data points $\left(\mathrm{N}_{\mathrm{ind}}\right)$ was determined using Stern's rule (Stern, 1993) as $2 \Delta \mathrm{k} \Delta \mathrm{R} / \pi+2$ (Booth and $\mathrm{Hu}, 2009)$ where $\Delta \mathrm{k}$ and $\Delta \mathrm{R}$ are the range in $\mathrm{k}$ and R-space actually fitted; as such, $\mathrm{N}_{\text {ind }}=14$. The number of fitted parameters $\left(\mathrm{N}_{\mathrm{par}}\right)$ was determined as the total number of parameters optimized during the various model refinements and was always less than $\mathrm{N}_{\text {ind. }}$ Typical errors associated with EXAFS modeling over the k-range used here are $15 \%$ and $25 \%$ for first and second shell coordination numbers, respectively, \pm 0.02 and $0.05 \AA$ for first and second shell distances, 
respectively, and 15\% and 25\% for first and second shell Debye-Waller factors (DWF's), respectively (Binsted, 1998). The quality of the fits provided by the different model clusters was assessed using the EXAFS R-factor and Fit Index, with an absolute index of goodness of fit (used for comparing fit quality between clusters where $\mathrm{N}_{\text {pars }}$ was not equivalent) given by the reduced $\mathrm{Chi}^{2}$ function (all as coded in EXCURV98 (Binsted et al., 1996; Binsted, 1998)).

\subsection{Micro X-ray Diffraction and Electron Microprobe mapping}

The work of Posth et al. (2013b) established that the post diagenetic mineralogy of these capsules consists of hematite when no organic carbon is present, and a mixture of hematite, magnetite, and siderite in the presence of organic carbon. As such, we examined the mineralogy, and $\mathrm{Zn}$ and $\mathrm{Ni}$ distribution of several key samples, in order to determine the mineralogy and $\mathrm{Zn}$ or Ni distributions following the re-oxidation of the post-diagenetic material. As described above, these samples had been removed from capsules after incubation, rinsed, and then filtered, and the filters retained. Following an 18-month re-oxidation period, the material from the filter was sonicated and then rinsed once in water (MilliQ, $\mathrm{pH} \sim 6.1$ ) and dried at $30^{\circ} \mathrm{C}$.

Dried samples of NiFh-1 and NiBF1 for mineral identification were loaded directly onto a Si single crystal silicon wafer for $\mu$ XRD. Data was collected with a Bruker D8 Discover XRD instrument (Bruker, Germany) equipped with a Co Ka X-ray tube, $(\lambda=0.17902 \mathrm{~nm}, 30 \mathrm{kV}, 30 \mathrm{~mA})$ and GADDS area detector. Minerals were identified with the International Center for Diffraction Data (ICDD) database. For spatially-resolved concentration analysis, dried particles from capsules ZnFh-2, NiFh-2, ZnBF2, and NiBF2 
were cast in epoxy resin and polished to $1 \mu \mathrm{m}$. Elemental concentration maps for $\mathrm{Fe}, \mathrm{Ni}$, and $\mathrm{Zn}$ were obtained using a Cameca SX100 electron probe micro-analyzer (EMPA), operating in quantitative mode with background subtraction at the facilities in Microsonde Ouest (Université of Brest/IFREMER). Beam operating conditions were 15 $\mathrm{kV}$ and $20 \mathrm{nA}$. Mineral standards for instrument calibration were andradite $\left(\mathrm{Ca}_{3} \mathrm{Fe}_{2} \mathrm{Si}_{3} \mathrm{O}_{12}\right)$ for $\mathrm{Fe}, \mathrm{ZnS}$ for $\mathrm{Zn}$, and $\mathrm{NiO}$ for Ni. Detection limits for $\mathrm{Fe}, \mathrm{Zn}$, and $\mathrm{Ni}$ were $0.0825 \%, 0.22 \%$ and $0.063 \%$, respectively. The precision on our EMPA analysis is estimated to be $\pm 1 \%$.

\section{Results}

\subsection{Sorption of $\mathrm{Zn}$ and $\mathrm{Ni}$}

Trace metals sorbed to the Fh at molar values of $4.856 \times 10^{-3} \mathrm{Zn} / \mathrm{Fe}$ and $3.918 \times 10^{-3}$ $\mathrm{Ni} / \mathrm{Fe}$. This corresponds to $93.98 \pm 0.54 \%$ of initial $\mathrm{Zn}$ and $65.95 \pm 1.29 \%$ of initial $\mathrm{Ni}$ being sorbed. For BF, molar ratios of $5.410 \times 10^{-3} \mathrm{Zn} / \mathrm{Fe}$ and $6.067 \times 10^{-3} \mathrm{Ni} / \mathrm{Fe}$ were sorbed, corresponding to $97.03 \pm 0.60 \%$ of initial $\mathrm{Zn}$ and $93.38 \pm 0.52 \%$ of initial $\mathrm{Ni}$ (see Table 1 for summary).

For the XAS spectrum of Ni initially sorbed to Fh (Fig. 1) we find that the first shell coordination environment consists of $6.0 \mathrm{O}$ at $\sim 2.0-2.09 \AA$, consistent with the octahedral $\mathrm{NiO}_{6} \mathrm{H}_{\mathrm{n}}{ }^{\mathrm{n}-10}$ ion (Table 3). Beyond the $\mathrm{O}$ shells, we observe a peak in the Fourier transform at $\sim 3.2 \AA$. Based on the literature to date, trace metals may sorb to Fe oxyhydroxides via outer-sphere and/or inner-sphere surface complexation, structural incorporation and/or be precipitated at the sorbent surface as a discrete metal oxyhydroxide phase (e.g., for a review see Brown and Parks, 2001). Because of the small 
difference in atomic number, distinguishing between $\mathrm{Ni}$ and Fe during EXAFS fitting is difficult. However, Ni structurally incorporated into Fh or present as a precipitate of poorly crystalline hydrated $\alpha-\mathrm{Ni}(\mathrm{OH})_{2}$ has unique features in k-space, including a shoulder at $\sim 5 \AA^{-1}$, a discrete peak at $\sim 5.5 \AA^{-1}$, and a pronounced splitting of the peak at $\sim 8 \AA$ (e.g., Xu et al., 2007; Pandya et al., 1990). We do not observe these features and rather our spectrum is visually similar to those for Ni surface complexed with Fh, where Ni forms inner-sphere mononuclear bidentate complexes (Xu et al., 2007). The presence of the Fourier transform peak at $\sim 3.2 \AA$ also rules out the likelihood of Ni outer sphere surface complexation where typically no next-nearest neighbours are observed. On refining model clusters for mononuclear monodentate, mononuclear bidentate edgesharing and mononuclear bidentate corner-sharing, we find that $\mathrm{Ni}$ adsorbed in a mononuclear bidentate corner-sharing configuration produces the best fit to the spectrum, with $6.0 \mathrm{O}$ at $2.0-2.09 \AA$ and $2.0 \mathrm{Fe}$ at 3.01 and $3.15 \AA$ (Table 3). With a single Ni-Fe

distance at $\sim 3.05 \AA$, Xu et al. (2007) invoked mononuclear bidentate edge-sharing surface complexation. However, within the constraints of a Ni-Fh mononuclear bidentate edge-sharing complex, the maximum Ni-Fe distance can be no longer that $\sim 3 \AA$ (assuming no significant distortion of the $\mathrm{Fe}$ and/or Ni octahedra) and this complex is, therefore, unable to provide a satisfactory fit to our data. In summary, in agreement with $\mathrm{Xu}$ et al. (2007), we find that $\mathrm{Ni}$ is initially sorbed to Fh via mononuclear bidentate surface complexation.

\subsection{Diagenetic experiments}


In the post-diagenetic experiments, $>99 \%$ of initially sorbed $\mathrm{Zn}$ is retained by the solid fractions in all scenarios, including controls (Table 2). Uncertainties are $\leq 4.3 \%$ for $\mathrm{Fh}$ capsules and $\leq 7.2 \%$ for BF capsules. Ni mobility is also low with $>91 \%$ of initially sorbed Ni retained on (1) Fh only, (2) Fh with added glucose, and (3) BF (Table 2). However, ICP-OES standard deviations were higher for $\mathrm{Ni}$, and associated uncertainties for the amount of Ni retained are up to $41.7 \%$, but generally $<17 \%$. This is likely due to Ni concentrations being close to detection limits following dilution prior to analysis. For the Fh only experiments (in the absence of organic carbon), effectively all $\mathrm{Ni}$ was retained (NiFh-4). However, replicate capsules with $\mathrm{Fh}$ and glucose retained the least amount of $\mathrm{Ni}$ after incubation, and had the highest uncertainties, $94.7 \pm 26.6 \%$ and 91.9 $\pm 41.7 \%$ (NiFh-1 and NiFh-2, respectively), while in BF capsules, $96.8 \pm 16.8 \%$ and $96.4 \pm 16.6 \%$ of Ni was retained (NiBF-1 and NiBF-2, respectively). Controls for Fh and BF capsules retained $99.8 \%$ (with $\leq 1.2 \%$ uncertainty) and $98.9 \%$ (with $\leq 7.9 \%$ uncertainty) of the initial $\mathrm{Ni}$, respectively. It should be noted that the lowest $\mathrm{Ni}$ values by percentage of Ni retained were associated with the highest uncertainties and it is possible that $100 \%$ of $\mathrm{Ni}$ was retained in these experiments. However, in our discussion, we take the lower values as a conservative representation of Ni mobility.

\section{$3.3 \mu X R D$ and Electron Microprobe Analysis}

Bulk mineralogy was analyzed by $\mu$ XRD on the two selected samples (NiFh-1 and NiBF1) from this study 18 months after the P-T incubations; during which time samples remained hydrated at $4^{\circ} \mathrm{C}$ in fully oxic conditions. In this regard, storage of the samples under oxic conditions for 18 months allowed us to determine mineralogy under post- 
depositional conditions reminiscent of secondary oxygenated fluids moving through the BIF.

The bulk mineralogy for the selected sample NiFh-1, after P-T incubation, and an 18-month oxidation period, revealed a well-crystalline hematite phase (see Fig. 2). A similar phase was also detected in identical incubations that did not include added trace elements (Posth et al., 2013b). However, in that study, peaks for siderite and magnetite, absent here, were also clearly visible. Any siderite and magnetite present initially after incubation would have been oxidized during subsequent storage, leaving only stable hematite. Interestingly, the NiBF1 sample bulk mineralogy included both hematite and lepidocrocite; the hematite peaks were also broader in NiBF1 than in NiFh-1, likely indicating a more poorly crystalline hematite phase. The persistence of poorly crystalline phases in the biogenic experiments suggests that the presence of organic carbon during mineral precipitation can stabilize poorly ordered iron oxyhydroxides (e.g., Schwertmann, 1966; Jambor and Dutrizac, 1998; Toner et al., 2012).

Samples subjected to EMPA analysis had similarly been stored under the oxic conditions. For all samples subjected to EMPA analysis, except $\mathrm{ZnFh}-2$, data indicate that $\mathrm{Ni}$ and $\mathrm{Zn}$ appear to be distributed as a function of $\mathrm{Fe}$ and no Ni- or $\mathrm{Zn}$-rich zones or discrete Ni or Zn mineral phases were observed (Figs. 3-4). In other words, despite the likely initial presence of siderite or magnetite, as observed by Posth et al. (2013b), those reduced phases were subsequently re-oxidized to hematite but without corresponding mobility of Ni or Zn. In the case of ZnFh-2 (Fig. 3A, B), Zn-rich (up to $3.5 \mathrm{wt} \% \mathrm{Zn}$ ) inclusions of 5-15 $\mu \mathrm{m}$ in diameter were observed encased in the hematite matrix. The $\mathrm{Zn}$ rich inclusions were also significantly more Fe-poor than the surrounding hematite matrix 
(but still contained 30-40 wt $\% \mathrm{Fe}$ ), suggesting the possibility of siderite (which is known to form a solid-solution series with smithsonite $\left.\left(\mathrm{ZnCO}_{3}\right)\right)$, prior to re-oxidation.

\section{Discussion}

\subsection{Sorption of $\mathrm{Zn}$ and $\mathrm{Ni}$}

In the Fh sorption experiments $93.38 \% \mathrm{Zn}$ and $65.95 \% \mathrm{Ni}$ were initially sorbed, while in the BF sorption experiments $97.03 \%$ of $\mathrm{Zn}$ and $93.38 \%$ of Ni were initially sorbed (Table 1). For both $\mathrm{Zn}$ and $\mathrm{Ni}$ in the $\mathrm{Fh}$ and $\mathrm{BF}$ experiments this is to be expected based on the sorption $\mathrm{pH}$ edges of these metals on $\mathrm{Fh}$ or other ferric oxyhydroxides (i.e., at $\mathrm{pH} 8$ sorption is essentially complete; e.g., Trivedi and Axe, 2001). It appears from our work that $\mathrm{Zn}$ has a somewhat higher affinity than Ni for both Fh and BF. This is in overall agreement with previous work on the general behavior of $\mathrm{Zn}$ and $\mathrm{Ni}$ when they sorb to ferrihydrite and hematite at ionic strength $<1.5 \mathrm{M}$ (e.g., Trivedi and Axe, 2001; Jeon et al., 2003). Although, the initial sorption of Ni to Fh here is less than expected, at only $65.95 \%$, this may reflect variable Fh particle surface reactivity (e.g., as a result of aggregation and/or freeze-drying prior to metal sorption). However, this does not appear to have affected its retention in the later diagenetic phases of the experiment. Critically, all $\mathrm{Fh}$ and $\mathrm{BF}$ were treated similarly in their preparation and sorption of $\mathrm{Zn}$ or $\mathrm{Ni}$, and overall the diagenetic mobility results are consistent across all the conditions considered. The sorption behavior of $\mathrm{Zn}$ and Ni likely affects their retention following diagenesis and will be discussed further in the context of the diagenetic mobility of $\mathrm{Zn}$ and Ni.

\subsection{Diagenetic mobility of $\mathrm{Zn}$ and $\mathrm{Ni}$}


Understanding diagenetic trace element mobility is critical for the interpretation of IF paleomarine proxies. Posth et al. (2013b) showed that pressure and temperature treatments of Fh and organic carbon produces a mineralogy similar to IF, dominated by hematite, magnetite and siderite. Accordingly, that approach formed the basis for our diagenetic experiments. Our results suggest that $\mathrm{Zn}$ is essentially immobile during Fe(III) mineral diagenesis. Specifically, there is no significant desorption in the unincubated controls (consistent with the observations of Lee and Anderson (2005) who showed $\mathrm{Zn}$ was immobile on Fh over six months). Furthermore, it is not significantly desorbed from Fh, Fh with added glucose or BF during simulated diagenesis (Table 2). This is evident as there was effectively no $\mathrm{Zn}$ in the fluids generated during diagenesis and recovered in the post-diagenetic rinse. The presence of organic matter did not affect Zn mobility and the lack of mobility in BF capsules is consistent with results from Fh capsules with added glucose (Table 2). Similarly, Ni shows no significant desorption in the unincubated controls or the Fh experiments (Table 2). Nickel may be slightly more mobile when organic carbon was present, but when uncertainties are considered, Ni is likely immobile during diagenesis (Table 2). Nickel was slightly desorbed from BF controls with $\sim 1.1 \%$ mobilized, whereas in Fh controls desorption was $<0.25 \%$ regardless of glucose.

The limited mobility of $\mathrm{Zn}$ and Ni likely relates to their behaviour during sorption. In agreement with Xu et al. (2007), we show that Ni strongly adsorbs to Fh via inner-sphere mononuclear bidentate surface complexation. It is also known that $\mathrm{Zn}$ can similarly adsorb strongly to the surfaces of amorphous and crystalline iron oxyhydroxides via inner-sphere surface complexes (e.g., for $\mathrm{Zn}$ on hydrous ferric oxide, Lee and Anderson, 2005; ferrihydrite, Waychunas et al., 2002, 2003; and goethite, Trivedi et al.. 
2001). Both Zn and Ni sorb more strongly to amorphous vs. crystalline Fe oxyhydroxide phases, such as ferrihydrite (Trivedi and Axe, 2001). For Fh, the percent sorbed for both $\mathrm{Zn}$ and $\mathrm{Ni}$ approaches $100 \%\left(5 \times 10^{-5} \mathrm{M} \mathrm{Zn}\right.$ or $\mathrm{Ni}$ and $1 \mathrm{~g} / \mathrm{L}$ ferrihydrite at $\left.25^{\circ} \mathrm{C}\right)$ as the pH approaches values of 6-8 (Trivedi and Axe, 2001). To the authors' knowledge there are no studies that determine the mechanism of $\mathrm{Zn}$ or Ni sorption on BF. However, Moon and Peacock $(2012,2013)$ showed that, similar to $\mathrm{Ni}, \mathrm{Cu}(\mathrm{II})$ adsorbs to Fh via innersphere mononuclear bidentate surface complexation, and adsorbs to the Fh fraction in ferrihydrite-bacteria composites via the same molecular mechanism as the isolated endmember Fh. Jeon et al. (2003) also showed that $\mathrm{Zn}$ and Ni sorbed rapidly to the surface of hematite, with a secondary stage of relatively slow sorption occurring over several days; where $\mathrm{Zn}$ sorbed more strongly to hematite than $\mathrm{Ni}$. The stronger sorption of $\mathrm{Zn}$ to $\mathrm{Fe}$ oxyhydroxides may be seen in the initial phase of this experiment (93.98\% $\mathrm{Zn}$ vs. $65.95 \%$ Ni sorbed on Fh, and $97.03 \%$ Zn vs. $93.38 \%$ Ni sorbed on BF; Table 1) and may account for its slightly greater retention following diagenetic capsule treatments (Table 2).

It is also known that during the transformation of $\mathrm{Fh}$ to goethite and hematite, $\mathrm{Ni}$ can be sequestered into the more crystalline mineral products (Ford et al., 1997). As well, $\mathrm{Zn}$ initially sorbed to Fh shows decreased solubility after aging and heat-induced phase transformation of the Fh to more crystalline Fe oxyhydroxides (Martínez and McBride, 1998). In both of the studies above, lead $(\mathrm{Pb})$ was excluded from the more crystalline, neo-formed phases following transformation from $\mathrm{Fh}$, possibly because it was not structurally incorporated into the neo-formed products (Ford et al., 1997; Martínez and McBride, 1998). More recently, several studies have directly demonstrated that tracemetals, including $\mathrm{Ni}$, can be structurally incorporated into crystalline Fe oxyhydroxides 
by isomorphic substitution with structural Fe (e.g., Carvalho-E-Silva et al., 2003). Work to date, therefore, suggests that following initial inner-sphere adsorption to Fh, both $\mathrm{Zn}$ and $\mathrm{Ni}$ will be strongly bound to the neo-forming, more crystalline Fe oxyhydroxides. This may be the result of either similar inner-sphere surface adsorption complexes and/or via structural incorporation into the neo-forming mineral phases. Although the precise molecular mechanisms responsible for $\mathrm{Zn}$ and $\mathrm{Ni}$ retention during diagenesis will require further study, the importance of our preliminary assessment lies with the empirical observation of strong metal retention during simulated IF diagenesis.

\subsection{Considerations on the diagenetic mobility of $\mathrm{Zn}$ and $\mathrm{Ni}$ and IF diagenesis}

Potentially increased Ni mobility from Fh plus glucose and BF (Table 2) may result from reactions involving electron transfer, such as the reduction of solid-phase $\mathrm{Fe}(\mathrm{III})$ to soluble Fe(II) coupled to the oxidation of organic carbon (e.g., Frierdich et al., 2011; Posth et al., 2013b). The potential presence of siderite in the post-diagenetic sample ZnFh-2 (see also Köhler et al., 2013; Posth et al., 2013b) would indicate that both Fe(III) and $\mathrm{Fe}(\mathrm{II})$ are present for the diagenetic formation of more crystalline mineral phases. This scenario would effectively represent a situation where there is dissimilatory Fe(III) reduction occurring due to the interaction of buried organic carbon with initial ferric oxyhydroxides (Konhauser et al, 2005; Johnson et al., 2008; Craddock and Dauphas, 2011), and suggests that organic carbon in IF depositional settings could lead to slight increases in diagenetic $\mathrm{Zn}$ and Ni mobility.

Indeed, a recent focus has been placed on the importance of the interaction of aqueous $\mathrm{Fe}(\mathrm{II})$ with the surface of ferric oxyhydroxides. Such reactions have been shown 
to cause phase changes, from initial $\mathrm{Fe}(\mathrm{OH})_{3}$ to secondary lepidocrocite, goethite and magnetite, and this process is generally rapid, occurring within days (e.g., Hansel et al, 2005). Similar studies utilizing $\mathrm{Fe}$ isotope tracers show a complete exchange of $\mathrm{Fe}$ atoms between the aqueous Fe(II) and Fe(III) oxide pools (e.g., Handler et al., 2009). The effect of these reactions on trace-metal mobility, thus far, are best represented by Frierdich et al. (2011) and Frierdich and Catalano (2012) who demonstrated that trace-metal-free Fe(II) solutions mobilize $\mathrm{Zn}$ and Ni from the Fe(III) surface pools of Fe(III) oxides. However, only $\sim 9 \%$ and $\sim 2 \%$ of incorporated $\mathrm{Ni}$ is lost from goethite and hematite, respectively, during a rapid approach to equilibrium conditions (Frierdich and Catalano, 2012). This metal loss during re-equilibration is generally on the order of the largest relative remobilization values we observe for our simulated diagenesis experiments. Furthermore, this mobility is relatively minor and likely to be secondary with respect to uncertainties associated with $K_{D}$ values predicted for the Precambrian. Moreover, the experiments above on trace metal mobilization by aqueous Fe(II) were performed on pure iron-oxide phases. It has subsequently been shown that the inclusion of insoluble elements (e.g., $\mathrm{Al}$, $\mathrm{Cr}$ and $\mathrm{Sn}$ ) within the Fe oxide lattice can impede Fe(II) induced phase changes (e.g., $\mathrm{Al}$, Hansel et al., 2011) and significantly reduce the release of $\mathrm{Ni}$ and $\mathrm{Zn}$ by inhibiting $\mathrm{Fe}$ atom exchange with $\mathrm{Fe}(\mathrm{II})$ (Frierdich et al., 2012). Given these considerations, this is a scenario likely to be more relevant for naturally occurring Fe oxide phases comprising IF.

We also consider that diagenetic re-equilibration will most likely not occur under open system conditions. IF are often considered to behave as a closed system during diagenesis, because the pore-waters are insulated from overlying seawater by layers of chert and iron oxides with vastly different surface charges (see McConchie, 1987). 
Essentially, neither cations nor anions would be able to freely diffuse back into the overlying water column. Instead, any Zn or Ni mobilized during the dehydration or reduction of primary ferric oxyhydroxides would most likely be rapidly sorbed by the neo-forming mineral phases (see section 4.2) or at least remain in the IF precursor sediment to be sorbed by recrystallized minerals during later burial diagenesis (e.g., Raiswell et al., 2011; Posth et al., 2013b; Köhler et al., 2013). Indeed, paleomarine reconstructions of seawater constituents from IF often rely on the preservation of marinelike rare earth element (REE) patterns as confirmation that authigenic seawater signatures were retained (e.g., Bau and Möller, 1993; Bolhar et al., 2004). These include the preservation of distinct $\mathrm{Eu} / \mathrm{Eu}^{*}$ anomalies observed in the $\mathrm{cm}$-scale bands of the Kuruman IF (e.g., Bau and Dulski, 1996). IF mesobands also retain inter- and intra-band variability in trace metal abundances, including $\mathrm{Zn}$ and Ni (e.g., Pecoits et al., 2009), and small-scale variability in inter- and intra-layer Fe isotope composition of IF (e.g., Frost et al., 2007; Whitehouse and Fedo, 2007; Steinhoefel et al., 2010). Collectively, these studies indicate limited post depositional alteration and that IF, to at least some extent, behaved as closed systems during diagenesis. To this end Konhauser et al. (2009) showed $\mathrm{Ni}$ concentrations were very similar in co-occurring hematite and magnetite grains despite the necessity for magnetite to have formed via diagenetic reactions.

During the transformation of ferrihydrite to hematite it is difficult to determine whether transformation occurred via a solid-state pathway instigated via heating ferrihydrite in the dry state (as performed here) or via an aqueous pathway technically achieved with added water present. This is because water produced from the dry state dehydration may provide sufficient water to instigate the aqueous pathway (Cornell and 
Schwertmann, 2003). Indeed, in our capsule experiments with $\sim 100 \mathrm{mg}$ Fh (estimated formula $\left.\mathrm{Fe}(\mathrm{OH})_{3}\right)$ about $25 \mathrm{mg}$ of water were released during dehydration, and when our capsules were opened, there was a liquid overpressure that was collected along with the buffered rinse solution for assessing the mobility of $\mathrm{Zn}$ and Ni. This liquid overpressure, the $25 \mathrm{mg}$ of water produced by the dehydration of Fh, should provide sufficient water to at least mimic IF diagenesis in a system that would almost certainly have been 'wet' to some extent. Additionally, within a very short reaction time ( $<14$ days) there is up to $10 \%$ Fe(II) formed when organic carbon is present (Posth et al., 2013b). Considering our Fh with added glucose experiments, and conservatively assuming only $1 \%$ of the generated Fe(II) will be in aqueous form, we can estimate just how much Fe(II) would be enriched in the liquid phase. This would translate as follows: for $\sim 1 \mathrm{mM}$ of initial $\mathrm{Fe}(\mathrm{III})$ present per capsule (100 mg Fh), about $100 \mu$ mol could potentially dissolve as Fe(II) in the water formed during Fh dehydration, leaving $1 \mu \mathrm{mol}$ of Fe(II) dissolved in $25 \mathrm{mg}$ of water (i.e. $25 \mu \mathrm{l}$ ) - a concentration of $0.04 \mathrm{M} \mathrm{Fe}(\mathrm{II})$. As the capsules are a closed system this would be free to react during ongoing diagenesis, and as such, represent an $\mathrm{Fe}(\mathrm{II})$-rich system where electron exchange could occur. This relatively conservative estimate for the Fe(II) concentrations available for diagenetic reaction in our capsule experiments are an order of magnitude greater than those used by Frierdich et al. (2011) of $2 \times 10^{-4}$ to $10^{-3} \mathrm{M}$. Such conditions should provide more than adequate $\mathrm{Fe}(\mathrm{II})$ concentrations to promote redox driven recrystallization (as described in Frierdich et al., 2011), and potential subsequent trace metal mobility. However, overall $\mathrm{Zn}$ and Ni mobility in the presence of glucose and with $\mathrm{BF}$ is still low in our experiments, indicating IF should largely retain authigenic signatures and not depart strongly from initially sorbed paleomarine abundances. From an 
empirical perspective, we emphasize that almost all $\mathrm{Zn}$ and $\mathrm{Ni}$ in our experiments was retained, even in capsules with organic carbon where magnetite and/or siderite are likely to have formed diagenetically (Posth et al., 2013b). Indeed, exposing the diagenetic mineral products to oxygenated conditions for 18 months, and thus inducing their reoxidation to hematite, we still observed minimal mobilization of $\mathrm{Ni}$ or $\mathrm{Zn}$. In other words, the trace metals sorbed to the sedimenting ferrihydrite particles in the water column remained in the sediment irrespective of secondary iron mineral. The observation of $\mathrm{Zn}$ rich inclusions in sample $\mathrm{ZnFh}-2$ further supports the stability of $\mathrm{Zn}$ and Ni following the secondary oxidation of reduced mineral phases.

\section{Future work}

We have expanded on the studies of Posth et al. (2013b) and Köhler et al. (2013) here as an important first step aimed at constraining our understanding of IF diagenesis and trace metal mobility. A current limitation of this work that restricts its absolute applicability to the Precambrian is the use of closed system conditions. Although IF were not "open" systems, dewatering of the initially hydrous sediments did indeed occur (Krapež et al., 2003). Favorably, here we observe limited mobility of both $\mathrm{Zn}$ and $\mathrm{Ni}$ during the dehydration of Fh and BF to hematite. Accordingly, future studies on IF diagenesis and the diagenetic mobility of trace metals should examine the effects of more open system conditions. Furthermore, many IF were altered during metamorphism to P-T conditions up to amphibolite facies $\left(500-600^{\circ} \mathrm{C}\right.$ and $\left.>3 \mathrm{kbar}\right)$, and as such, an assessment of metal mobility under these conditions will ultimately be required. Future experiments may also include other trace metals, such as $\mathrm{Cr}$, Co, and REE, and varied types of organic carbon 
to assess what role more recalcitrant carbon may have on $\mathrm{Fe}(\mathrm{III})$ reduction and potential trace metal mobility. A number of studies have been published with regards to molecularlevel trace metal complexation by Fe oxyhydroxides (e.g., for a review see Brown and Parks, 2001); for Zn sorbed on ferrihydrite see Waychunas et al., 2002, 2003; for Ni sorbed on ferrihydrite see $\mathrm{Xu}$ et al., 2007, and for Ni incorporated into goethite see Carvalho-E-Silva et al., 2003). Increasingly, these studies have also looked at the trace metal complexation by bacteria (e.g., Boyanov et al., 2003; Toner et al., 2005; Moon and Peacock, 2011). Given the utility of such studies, future work should employ similar synchrotron radiation-based techniques (e.g., XAS) to help track the mobility of trace metals during Fe oxyhydroxide mineralogical transformation. This approach would help determine the mechanism(s) underpinning trace metal retention in the final neo-formed phases. Despite the multitude of potential work, we emphasize that our study here is a necessary first step, and the finding of $\mathrm{Zn}$ and $\mathrm{Ni}$ being immobile during simulated diagenesis is promising for the continued use of IF as paleomarine proxies.

\section{Conclusions}

Pressure and temperature treatments of $\mathrm{Fh}$ and carbon at conditions realistic for IF diagenesis $\left(170^{\circ} \mathrm{C}\right.$ and $\left.1.2 \mathrm{kbar}\right)$ demonstrated that $\mathrm{Zn}$ and $\mathrm{Ni}$ remained largely immobile. This suggests that IF retain authigenic signatures, and that paleomarine $\mathrm{Zn}$ and Ni values derived from the IF record (Konhauser et al., 2009; Robbins et al., 2013) are likely to be within the correct order of magnitude. Overall, it is consistent with indications from REE patterns and other geochemical data that IF faithfully record authigenic enrichments 
derived from ambient seawater, thus providing further impetus for exploration of IF as an important archive of the chemical history of seawater and early Earth evolution.

\section{Acknowledgements}

We thank James M. Byrne, Ellen Struve, Simone Kaulfuss, and Sabine Flaiz at the University of Tübingen for their assistance with sample preparation and analyses. Funding to L.J.R (CGSM) and K.O.K (Discovery Grant) was provided by NSERC. E.D.S. and A.K. were supported by Deutsche Forschungsgemeinschaft grant KA 1736/24-1 to A.K. E.D.S was also supported by NSF grant (no. 1064391), and S.V.L by a LabexMER postdoctoral fellowship. CP was supported by NERC grant NE/F00043X/1. We also thank Diamond Light Source Ltd. for access to beamline B18 (proposal SP8624) that contributed to the results presented here. The authors thank Albertus Smith and a second anonymous reviewer, as well as the editor Michael Böttcher, for comments that greatly improved this manuscript.

\section{References}

Bau, M., Möller, P., 1993. Rare earth element systematics of the chemically precipitated component in Early Precambrian iron formations and the evolution of the terrestrial atmosphere-hydrosphere-lithosphere system. Geochim. Cosmochim. Acta 57, 22392249.

Bau, M., Dulski, P., 1996. Distribution of yttrium and rare-earth elements in the Penge and Kuruman iron-formations, Transvaal Supergroup, South Africa. Precambrian Res. 79, 37-55. 
Becker, R.H., Clayton, R.N., 1976. Oxygen isotope study of a Precambrian banded ironformation, Hamersley Range, Western Australia. Geochim. Cosmochim. Acta 40, 1153-1165.

Bekker, A., Slack, J.F, Planavsky, N., Krapež, B., Hofmann, A., Konhauser, K.O., Rouxel, O.J., 2010. Iron formation: the sedimentary product of a complex interplay among mantle, tectonic, oceanic, and biospheric processes. Econ. Geol. 105, 467508.

Binsted, N., Pack, M.J., Weller, M.T., Evans, J., 1996. Combined EXAFS and Powder Diffraction Analysis. J. Am. Chem. Soc. 118, 10200-10210.

Binsted, N., 1998. EXCURV98 - The Manual. CLRC Daresbury Laboratory Program., Warrington, United Kingdom.

Bolhar, R., Kamber, B.S., Moorbath, S., Fedo, C.M., Whitehouse, M.J., 2004.

Characterisation of early Archaean chemical sediments by trace element signatures. Earth. Planet. Sci. Lett. 222, 43-60.

Booth, C.H., Hu, Y.-J., 2009. Confirmation of standard error analysis techniques applied to EXAFS using simulations. J. Phys. Conf. Ser. 190, 1-6.

Boyanov, M.I., Kelly, S.D., Kemner, K.M., Bunker, B.A., Fein, J.B., Fowle, D.A., 2003. Adsorption of cadmium to Bacillus subtilis bacterial cell walls: A pH-dependent Xray absorption fine structure spectroscopy study. Geochim. Cosmochim. Acta 67, 3299-3311.

Brown, G.E., Jr., Parks, G.A., 2001. Sorption of Trace Elements on Mineral Surfaces: Modern Perspectives from Spectroscopic Studies, and Comments on Sorption in the Marine Environment. Int. Geol. Rev. 43, 963-1073. 
Carvalho-E-Silva, M.L., Ramos, A.Y., Tolentino, H.C.N., Enzweiler, J., Netto, S.M., Alves, M.C.M., 2003. Incorporation of Ni into natural goethite: An investigation by X-ray absorption spectroscopy. Am. Mineral. 88, 876-882.

Cornell, R.M., Schwertmann, U., 2003. The iron oxides: structure, properties, reactions, occurrences and uses, $2^{\text {nd }}$ edition. Weinheim, Viley-VCH Verlag, pp. 1-664.

Craddock, P.R., Dauphas, N., 2011. Iron and carbon isotope evidence for microbial iron respiration throughout the Archean. Earth Planet. Sci. Lett. 303, 121-132.

Dupont, C.L., Butcher, A., Valas, R.E., Bourne, P.E., Caetano-Anollés, G., 2010. History of biological metal utilization inferred through phylogenomic analysis of protein structures. Proc. Natl. Acad. Sci. 107, 10567-10572.

Eickhoff, M., 2013. Biomarker, Trace Metal and Diagenesis Studies with FeMetabolizing Bacteria to Better Understand Their Role on Early Earth. PhD Thesis. University of Tübingen, Germany.

Eickhoff, M., Obst, M., Schröder, C., Hitchcock, A.P., Tyliszczak, T., Martinez, R.E., Robbins, L.J., Konhauser, K.O., Kappler, A., 2014. Nickel partitioning in biogenic and abiogenic ferrihydrite: The influence of silica and implications for ancient environments. Geochim. Cosmochim. Acta 140, 65-79.

Ford, R.G., Bertsch, P.M., Farley, K.J., 1997. Changes in Transition and Heavy Metal Partitioning during Hydrous Iron Oxide Aging. Environ. Sci. Technol. 31: 20282033.

Frierdich, A.J., Luo, Y., Catalano, J.G., 2011. Trace element cycling through iron oxide minerals during redox driven dynamic recrystallization. Geology 39, 1083-1086. 
Frierdich, A.J., Catalano, J.G., 2012. Controls on Fe(II)-Activated Trace Element Release from Goethite and Hematite. Environ. Sci. Technol. 46, 1519-1526.

Frierdich, A.J., Scherer, M.M., Bachman, J.E., Engelhard, M.H., Rapponotti, B.W., Catalano, J.G., 2012. Inhibition of trace element release during Fe(II)-activated recrystallization of Al-, Cr-, and Sn-substituted goethite and hematite. Environ. Sci. Technol. 46, 10031-10039.

Frost, C.D., von Blanckenburg, F., Schoenberg, R., Frost, B.R., Swapp, S.M., 2007. Preservation of $\mathrm{Fe}$ isotope heterogeneities during diagenesis and metamorphism of banded iron formation. Contrib. Mineral. Petrol. 153, 211-235.

Gole, M.J., Klein, C., 1981. Banded Iron-Formations though much of Precambrian Time. J. Geol. 89, 169-183.

Handler, R.M., Beard, B.L., Johnson, C.M., Scherer, M.M., 2009. Atom Exchange between Aqueous Fe(II) and Goethite: An Fe Isotope Tracer Study. Environ. Sci. Technol. 43, 1102-1107.

Hansel, C.M., Benner, S.G., Fendorf, S., 2005. Competing Fe(II)-Induced Mineralization Pathways of Ferrihydrite. Environ. Sci. Technol. 39, 7147-7153.

Hansel, C.M., Learman, D.R., Lentini, C.J., Ekstrom, E.B., 2011. Effect of adsorbed and substituted $\mathrm{Al}$ on $\mathrm{Fe}(\mathrm{II})$-induced mineralization pathways on ferrihydrite. Geochim. Cosmochim. Acta 75, 4653-4666.

Heimann, A., Johnson, C.M., Beard, B.L., Valley, J.W., Roden, E.E., Spicuzza, M.J., Beukes, N.J., 2010. Fe, C, and O isotope compositions of banded iron formation carbonates demonstrate a major role for dissimilatory iron reduction in $\sim 2.5 \mathrm{Ga}$ marine environments. Earth Planet. Sci. Lett. 294, 8-18. 
Jambor, J.L., Dutrizac, J.E., 1998. Occurrence and constitution of natural and synthetic ferrihydrite, a wide-spread iron oxyhydroxides. Chem. Rev. 98, 2549-2585.

Jeon, B.-H., Dempsey, B.A., Burgos, W.D., Royer, R.A., 2003. Sorption kinetics of $\mathrm{Fe}(\mathrm{II}), \mathrm{Zn}(\mathrm{II}), \mathrm{Co}(\mathrm{II}), \mathrm{Ni}(\mathrm{II}), \mathrm{Cd}(\mathrm{II})$ and $\mathrm{Fe}(\mathrm{II}) / \mathrm{Me}(\mathrm{II})$ onto hematite. Water Res. 37, $4135-4142$.

Johnson, C.M., Beard, B.L., Klein, C., Beukes, N.J., Roden, E.E., 2008. Iron isotopes constrain biologic and abiologic processes in banded iron formation genesis: Geochim. Cosmochim. Acta 72, 151-169.

Klein, C., 2005. Some Precambrian banded iron-formations (BIFs) from around the world: Their age, geologic setting, mineralogy, metamorphism, geochemistry and origins. Am. Mineral. 90: 1473-1499.

Köhler, I., Konhauser, K.O., Papineau, D., Bekker, A., Kappler, A., 2013. Biological carbon precursor to diagenetic siderite with spherical structures in iron formations. Nat. Commun. doi. 10.1038/ncomms2770.

Konhauser, K.O., 2007. Introduction to Geomicrobiology. Oxford, United Kingdom, Blackwell Publishing. pp. 1-425.

Konhauser, K.O., Newman, D.K., Kappler, A., 2005. The potential significance of microbial Fe(III) reduction during deposition of Precambrian banded iron formations: Geobiology 3, 167-177.

Konhauser, K.O., Pecoits, E., Lalonde, S.V., Papineau, D., Nisbet, E.G. Barley, M.E., Arndt, N.T., Zahnle, K., Kamber, B.Z., 2009. Oceanic nickel depletion and a methanogen famine before the Great Oxidation Event. Nature 458, 750-753. 
Krapež, B., Barley, M.E., Pickard, A.L., 2003. Hydrothermal and resedimented origins of the precursor sediments to banded iron formation: sedimentological evidence from the Early Palaeoproterozoic Brockman Supersequence of Western Australia. Sedimentology 50: 979-1011.

Lee, S., Anderson, P.R., 2005. EXAFS study of Zn sorption on hydrous ferric oxide over extended reaction time. J. Colloid Interf. Sci. 286, 82-89.

Martínez, C.E., McBride, M.B., 1998. Coprecipitates of Cd, Cu, Pb, and $\mathrm{Zn}$ in iron oxides: solid phase transformation and metal solubility after aging and thermal treatment. Clay. Clay. Miner. 46: 537-545.

McConchie, D., 1987. The geology and geochemistry of the Joffre and Whaleback shale members of the Brockman Iron Formation, Western Australia. In: Appel, P.W.U., LaBerge, G.L. (Eds.), Precambrian iron-formations. Athens, Theophrastus, pp. 541597.

Miyano, T., Klein, C., 1984. Evaluation of the stability relations of amphibole asbestos in metamorphosed iron formations. Min. Geol. 33, 213-222.

Miyano, T., 1987. Diagenetic to low-grade metamorphic conditions of Precambrian iornformations. In: Appel, P.W.U., LaBerge, G.L. (Eds.), Precambrian iron-formations. Athen, Theophrastus, pp. 155-186.

Mloszewska, A.M., Pecoits, E., Cates, N.L., Mojzsis, S.J., O’Neil, J., Robbins, L.J., Konhauser, K.O., 2012. The composition of Earth's oldest iron formations: The Nuvvuagittuq Supracrustal Belt (Québec, Canada). Earth. Planet. Sci. Lett. 317-318: $331-342$. 
Moon, E.M., Peacock, C.L., 2011. Adsorption of Cu(II) to Bacillus subtilis: A pHdependent EXAFS and thermodynamic modelling study. Geochim. Cosmochim. Acta 75, 6705-6719.

Moon, E.M., Peacock, C.L., 2012. Adsorption of Cu(II) to ferrihydrite and ferrihydritebacteria composites: Importance of the carboxyl group for $\mathrm{Cu}$ mobility in natural environments. Geochim. Cosmochim. Acta 92, 203-219.

Moon, E.M., Peacock, C.L., 2013. Modelling Cu(II) adsorption to ferrihydrite and ferrihydrite-bacteria composites: Deviation from additive adsorption in the composite sorption system. Geochim. Cosmochim. Acta 104, 148-164.

Pandya, K.I., O’Grady, W.E., Corrigan, D.A., McBreen, J., Hoffman, R.W., 1990. Extended X-ray Absorption Fine Structure Investigations of Nickel Hydroxides. J. Phys. Chem. 94, 21-26.

Pecoits, E., Gingras, M.K., Barley, M.E., Kappler, A., Posth, N.R., Konhauser, K.O., 2009. Petrography and geochemistry of the Dales Gorge banded iron formation: Paragenetic sequence, source, and implication for palaeo-ocean chemistry. Precambrian Res. 172, 163-187.

Pecoits, E., Smith, M.L., Catling, D.C., Philippot, P., Kappler, A., and Konhauser, K.O., 2015. Atmospheric hydrogen peroxide and Eoarchean iron formations. Geobiology, $13,1-14$.

Perry, E.C., Tan, F.C., Morey, G.B., 1973. Geology and Stable Isotope Geochemistry of the Biwabik Iron Formation, Northern Minnesota: Econ. Geol. 68, 1110-1125. 
Posth, N.R., Konhauser, K.O., and Kappler, A., 2013a. Microbiological processes in banded iron formation deposition. Sedimentology 60, 1733-1754.

Posth, N.R., Köhler, I., Swanner, E.D., Schröder, C., Wellmann, E., Binder, B., Konhauser, K.O., Neumann, U., Berthold, C., Nowak, M., Kappler, A., $2013 b$. Simulating Precambrian banded iron formation diagenesis. Chem. Geol. 362, 66-73.

Posth, N.R., Canfield, D.E., Kappler, A., 2014. Biogenic Fe(III) minerals: from formations to diagenesis and preservation in the rock record. Earth-Sci. Rev. 135, $103-121$.

Raiswell, R., Reinhard, C.T., Derkowski, A., Owens, J., Bottrell, S.H., Anbar, A.D., Lyons, T.W., 2011. Formation of syngenetic and early diagenetic iron mineral in the late Archean Mt. McRae Shale, Hamersley Basin, Australia: New insights on the patterns, controls, and paleoenvironmental implications of authigenic mineral formation. Geochim. Cosmochim. Acta 75, 1072-1087.

Ravel, B., Newville, M., 2005. ATHENA, ARTEMIS, HEPHAESTUS: data analysis for Xray absorption spectroscopy using IFEFFIT. J. Synchrotron Radiat. 12, 537-541.

Robbins, L.J., Lalonde, S.V., Saito, M.A., Planavsky, N.J., Mloszewska, A.M., Pecoits, E., Scott, C., Dupont, C.L., Kappler, K.A., Konhauser, K.O., 2013. Authigenic iron oxide proxies for marine zinc over geological time and implications for eukaryotic metallome evolution. Geobiology 11, 295-306.

Saito, M.A., Sigman, D.M., Morrel, F.M.M., 2003. The bioinorganic chemistry of the ancient ocean: the co-evolution of cyanobacterial metal requirements and biogeochemical cycles at the Archean-Proterozoic boundary? Inorg. Chim. Acta 356: 308-318. 
Schwertmann, U., 1966. Inhibitory Effect of Soil Organic Matter on the Crystallization of Amorphous Ferric Hydroxide. Nature 212, 645-646.

Scott, C., Planavsky, N.J., Dupont, C.L., Kendall, B., Gill, B., Robbins, L.J., Husband, K.F., Arnold, G.L., Wing, B., Poulton, S.W., Bekker, A., Anbar, A.D., Konhauser, K.O., Lyons, T.W., 2013. Bioavailability of zinc in marine systems through time: Nature Geosci. 6, 125-128.

Smith, A.J.B., Beukes, N.J., Gutzmer, J., 2013. The composition and depositional environments of Mesoarchean Iron Formations of the West Rand Group of the Witwatersrand Supergroup, South Africa. Econ. Geol. 108: 111-134.

Steinhoefel, G., von Blanckenburg, F., Horn, I., Konhauser, K.O., Beukes, N.J., Gutzmer, J., 2010. Deciphering formation processes of banded iron formations from the Transvaal and the Hamersley successions by combined $\mathrm{Si}$ and $\mathrm{Fe}$ isotope analysis using femtosecond laser ablation. Geochim. Cosmochim. Acta 74, 2677-2696.

Stern, E.A., 1993. Number of relevant independent points in x-ray-absorption finestructure spectra. Phys. Rev. B 48, 9825-9827.

Stookey, L.L., 1970. Ferrozine - a new spectrophotometric reagent for iron. Anal. Chem. 42, 79-781.

Tomić, S., Searle, B.G., Wander, A., Harrison, N.M., Dent, A.J., Mosselmans, J.F.W., Inglesfield, J.E., 2005. New Tools for the Analysis of EXAFS: The DL_EXCURV Package. CCLRC Technical Report DL-TR-2005-001. Daresbury, United Kingdom. Toner, B., Manceau, A., Marcus, M.A., Millet, D.B., and Sposito, G., 2005. Zinc Sorption by a Bacterial Biofilm. Environ. Sci. Technol. 39, 8288-8294. 
Toner, B.M., Berquó, T.S., Michel, F.M., Sorensen, J.V., Templeton, A.S., Edwards, K.J., 2012. Mineralogy of Iron Microbial Mats from Loihi Seamount. Front. Microbiol. 3, 1-18.

Trivedi, P., Axe, L., 2001. Ni and Zn Sorption to Amorphous versus Crystalline Iron Oxides: Macroscopic Studies. J. Colloid Interf. Sci. 224, 221-229.

Trivedi, P., Axe, L., Tyson, T.A., 2001. An Analysis of Zinc Sorption to Amorphous versus Crystalline Iron Oxide Using XAS. J. Colloid. Interf. Sci. 244, 230-238.

Waychunas, G.A., Fuller, C.C., Davis, J.A., 2002. Surface complexation and precipitate geometry for aqueous $\mathrm{Zn}(\mathrm{II})$ sorption on ferrihydrite I: X-ray absorption extended fine structure spectroscopy analysis. Geochim. Cosmochim. Acta 66: 1119-1137.

Waychunas, G.A., Fuller, C.C., Davis, J.A., Rehr, J.J., 2003. Surface complexation and precipitate geometry for aqueous $\mathrm{Zn}$ (II) sorption on ferrihydrite: II. XANES analysis and simulation. Geochim. Cosmochim. Acta 67: 1031-1043.

Whitehouse, M.J., Fedo, C.M., 2007. Microscale heterogeneity of Fe isotopes in >3.71

Ga banded iron formation from the Isua Greenstone Belt, southwest Greenland. Geology 35, 719-722.

Williams, R.J.P., da Silva, J.J.R.F., 1996. The Natural Selection of the Chemical Elements. Bath Press Ltd., Great Britain.

Wu, W., Swanner, E.D., Hao, L., Zeitvogel, F., Obst, M., Pan, Y., Kappler, A., 2014. Characterization of the physiology and cell-mineral interactions of the marine anoxygenic phototrophic Fe(II) oxidizer Rhodovulum iodosum - implications for Precambrian banded iron formation deposition. FEMS Microbiol. Ecol. 88, 503-515. 
Xu, Y., Axe, L., Boonfueng, T., Tyson, T.A., Trivedi, P., Pandya, K., 2007. Ni(II)

complexation to amorphous hydrous ferric oxide: An X-ray absorption spectroscopy study. J. Colloid Interf. Sci. 314, 10-17.

\section{Table and Figure Captions}

Table 1. Adsorption of $\mathrm{Zn}$ and $\mathrm{Ni}$ to 2-line synthetic, and biogenic ferrihydrite. Errors are presented as percentages of two standard deviations of the ICP-OES analyses; molar values are presented without errors.

Table 2. Amount of $\mathrm{Zn}$ or Ni mobilized from Fe minerals and percent retained following 14 days incubation at $170^{\circ} \mathrm{C}$ and 1.2 kbar. Unincubated controls are denoted by a precursor $\mathrm{C}$. The trace metal (TM) in column names refers to either $\mathrm{Zn}$ or $\mathrm{Ni}$; a description of capsule contents is provided including the TM adsorbed ( $\mathrm{Zn}$ or $\mathrm{Ni}$ ), type of Fe particle (Fh or BF) and if glucose was added $(\mathrm{G})$. Errors in TM retained are presented as percentages based on two standard deviations of the ICP-OES analyses. For all samples where the respective plus or minus errors in TM retained differed, we have reported the larger error value.

Table 3. Ni K-edge EXAFS fit for Ni-sorbed ferrihydrite. Where $\mathrm{N}$ is the number of atoms in a shell, $\mathrm{R}$ is the distance of the atom in a shell from the Ni central absorber, $\sigma$ is the Debye-Waller factor (DWF), and $\theta$ and $\varphi$ are the spherical coordinates of each atom in a shell. EF is the correction to the Fermi energy value set in ATHENA. During 
optimization, values in italics were held constant and DWF's for the oxygen shells were constrained to be equal; $N_{\text {ind }}$ (number of independent data points) $=14, N_{\text {pars }}$ (number of parameters optimized) $=12$.

Figure 1. (a) EXAFS and (b) Fourier transform of the EXAFS for Ni sorbed to ferrihydrite. Solid lines are data, dotted lines are fit. (c) Molecular cluster used to fit the EXAFS data, where $\mathrm{O}_{1}-\mathrm{O}_{6}=$ octahedral oxygen atoms in $\mathrm{Ni}$ first shell coordination sphere and $\mathrm{Fe}_{1}-\mathrm{Fe}_{2}=$ iron in ferrihydrite $\mathrm{Fe}$ octahedra.

Figure 2. Micro-XRD patterns for NiBF1 and NiFh-1, collected after 18 months of sample storage at $4^{\circ} \mathrm{C}$ in oxic conditions. Both samples have reflections characteristic of hematite, but the different in peak broadness suggests hematite in NiBF1 is a less crystalline phase. NiBF1 additionally has reflections consistent with lepidocrocite ( $\gamma$ $\mathrm{FeOOH})$, an $\mathrm{Fe}(\mathrm{III})$ oxyhydroxide mineral.

Figure 3. Electron microprobe maps showing the distribution and weight percent for (A) $\mathrm{Fe}$ and (B) Zn in sample ZnFh-2, and (C) Fe and (D) Ni in sample NiFh-2. Color bars indicate the weight percent $( \pm 1 \%)$ of the corresponding element.

Figure 4. Electron microprobe maps showing the distribution and weight percent for (A) $\mathrm{Fe}$ and (B) $\mathrm{Zn}$ in sample ZnBF2, and (C) Fe and (D) Ni in sample NiBF2. Color bars indicate the weight percent $( \pm 1 \%)$ of the corresponding element. 
Table 1.

\begin{tabular}{|c|c|c|c|c|c|c|c|c|c|c|}
\hline $\begin{array}{c}\text { Mineral + TM } \\
\text { Combination }\end{array}$ & $\begin{array}{c}\text { Mass of Fe } \\
\text { particles } \\
\text { (g) }\end{array}$ & $\mathrm{Fe}(\mathrm{mol})$ & $\begin{array}{c}\text { Initial Solution } \\
\text { [TM] (mg/L) }\end{array}$ & $\begin{array}{c}\text { Final Solution } \\
{[\mathrm{TM}](\mathrm{mg} / \mathrm{L})}\end{array}$ & $\begin{array}{l}\text { Volume of TM } \\
\text { solution (L) }\end{array}$ & $\begin{array}{c}\text { TM } \\
\text { adsorbed } \\
\left(\mathbf{x 1 0 ^ { - 5 }} \mathrm{mol}\right)\end{array}$ & $\begin{array}{c}\% \mathrm{TM} \\
\text { adsorbed }\end{array}$ & $\begin{array}{c}\text { TM/Fe-particles } \\
\left(\times 10^{-5} \mathrm{~mol} / \mathrm{g}\right)\end{array}$ & $\begin{array}{c}\mathrm{mol} \mathrm{Zn/mol} \mathrm{Fe} \\
\left(x_{10}^{-3}\right)\end{array}$ & $\begin{array}{c}\mathrm{mol} \mathrm{Ni/mol} \mathrm{Fe} \\
\left(\times 10^{-3}\right)\end{array}$ \\
\hline $\begin{array}{l}\text { Zn on 2-line synthetic } \\
\text { ferrihydrite }\end{array}$ & 1.0224 & 0.0096 & $3.24 \pm 0.08$ & $0.20 \pm 0.01$ & 0.9987 & 4.646 & $93.98 \pm 0.54$ & 4.544 & 4.856 & 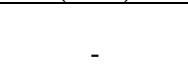 \\
\hline $\begin{array}{l}\mathrm{Ni} \text { on 2-line synthetic } \\
\text { ferrihydrite } \\
\mathrm{Zn} \text { on biogenic }\end{array}$ & 0.9965 & 0.0093 & $3.25 \pm 0.07$ & $1.11 \pm 0.02$ & 1.0019 & 3.653 & $65.95 \pm 1.29$ & 3.666 & - & 3.918 \\
\hline $\begin{array}{l}\text { ferrihydrite } \\
\text { Ni on biogenic }\end{array}$ & 0.5023 & 0.0044 & $3.23 \pm 0.16$ & $0.10 \pm 0.01$ & 0.4952 & 2.373 & $97.03 \pm 0.60$ & 4.725 & 5.410 & - \\
\hline ferrihydrite & 0.4769 & 0.0042 & $3.20 \pm 0.14$ & $0.21 \pm 0.01$ & 0.4964 & 2.527 & $93.38 \pm 0.52$ & 5.299 & - & 6.067 \\
\hline
\end{tabular}


Table 2.

\begin{tabular}{|c|c|c|c|c|c|c|c|c|c|c|c|c|}
\hline Capsule & $\begin{array}{c}\text { Mass Fe } \\
\text { particles } \\
(\mathrm{g})\end{array}$ & $\begin{array}{c}\text { Mass } \\
\text { Glucose } \\
(\mathrm{g})\end{array}$ & 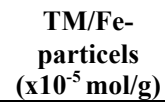 & $\begin{array}{c}\text { TM/capsule } \\
\left(\times 10^{-6} \mathrm{~mol}\right)\end{array}$ & $\begin{array}{c}\mathrm{Zn} \\
\text { released } \\
\left(\mathbf{x 1 0 ^ { - 9 }} \mathrm{mol}\right) \\
\end{array}$ & $\begin{array}{c}\text { Ni released } \\
\left(\times 10^{-9} \mathrm{~mol}\right)\end{array}$ & $\begin{array}{c}\% \mathrm{TM} \\
\text { retained }\end{array}$ & $\begin{array}{c}\text { TM ICP-OES } \sigma \\
(\mathrm{mg} / \mathrm{L})\end{array}$ & $\begin{array}{c} \pm 2 \sigma \mathrm{TM} \\
\text { ICP-OES } \\
\left(\mathrm{x} 10^{-9} \mathrm{~mol}\right)\end{array}$ & $\begin{array}{c} \pm 2 \sigma \mathrm{TM} \\
\text { retained } \\
(\%) \\
\end{array}$ & $\begin{array}{c}\text { Capsule } \\
\text { Contents } \\
\end{array}$ & C:Fe ratio \\
\hline $\mathrm{ZnFh}-2$ & 0.1000 & 0.0041 & 4.544 & 4.543 & 0.000 & 11.498 & 100.0 & 0.0031 & 94.79 & 2.1 & $\mathrm{Zn}+\mathrm{Fh}+\mathrm{G}$ & 0.1449 \\
\hline ZnFh-3 & 0.1000 & - & 4.544 & 4.543 & 0.000 & 0.327 & 100.0 & 0.0031 & 94.79 & 2.1 & $\mathrm{Zn}+\mathrm{Fh}$ & N/A \\
\hline $\mathrm{ZnFh}-4$ & 0.1000 & - & 4.544 & 4.546 & 0.000 & 0.000 & 100.0 & 0.0024 & 73.38 & 1.6 & $\mathrm{Zn}+\mathrm{Fh}$ & N/A \\
\hline C-ZnFh1 & 0.1000 & 0.0041 & 4.544 & 4.542 & 0.000 & 0.000 & 100.0 & 0.0064 & 195.7 & 4.3 & $\mathrm{Zn}+\mathrm{Fh}+\mathrm{G}$ & 0.1446 \\
\hline $\mathrm{C}-\mathrm{ZnFh} 2$ & 0.1000 & 0.0041 & 4.544 & 4.543 & 0.000 & 0.000 & 100.0 & 0.0030 & 91.73 & 2.0 & $\mathrm{Zn}+\mathrm{Fh}+\mathrm{G}$ & 0.1453 \\
\hline $\mathrm{C}-\mathrm{ZnFh} 3$ & 0.1000 & - & 4.544 & 4.544 & 0.000 & 0.000 & 100.0 & 0.0033 & 100.9 & 2.2 & $\mathrm{Zn}+\mathrm{Fh}$ & N/A \\
\hline $\mathrm{C}-\mathrm{ZnFh} 4$ & 0.1000 & - & 4.544 & 4.546 & 0.000 & 0.000 & 100.0 & 0.0029 & 88.67 & 2.0 & $\mathrm{Zn}+\mathrm{Fh}$ & N/A \\
\hline $\mathrm{ZnBF} 2$ & 0.0341 & - & 4.725 & 1.610 & 0.000 & 0.499 & 100.0 & 0.0036 & 110.1 & 6.8 & $\mathrm{Zn}+\mathrm{BF}$ & 0.1792 \\
\hline $\mathrm{ZnBF} 3$ & 0.0363 & - & 4.725 & 1.713 & 5.724 & 0.164 & 99.7 & 0.0020 & 61.15 & 3.9 & $\mathrm{Zn}+\mathrm{BF}$ & 0.1792 \\
\hline C-ZnBF1 & 0.0353 & - & 4.725 & 1.666 & 14.863 & 1.338 & 99.1 & 0.0029 & 88.67 & 6.2 & $\mathrm{Zn}+\mathrm{BF}$ & 0.1792 \\
\hline C-ZnBF2 & 0.0351 & - & 4.725 & 1.658 & 0.000 & 0.000 & 100.0 & 0.0039 & 119.2 & 7.2 & $\mathrm{Zn}+\mathrm{BF}$ & 0.1792 \\
\hline NiFh-1 & 0.1000 & 0.0041 & 3.666 & 3.666 & 0.000 & 193.557 & 94.7 & 0.0229 & 780.3 & 26.6 & $\mathrm{Ni}+\mathrm{Fh}+\mathrm{G}$ & 0.1456 \\
\hline NiFh-2 & 0.1000 & 0.0041 & 3.666 & 3.665 & 0.000 & 298.692 & 91.9 & 0.0361 & 1230 & 41.7 & $\mathrm{Ni}+\mathrm{Fh}+\mathrm{G}$ & 0.1445 \\
\hline NiFh-4 & 0.1001 & - & 3.666 & 3.669 & 0.000 & 0.166 & 100.0 & 0.0003 & 10.22 & 0.3 & $\mathrm{Ni}+\mathrm{Fh}$ & N/A \\
\hline C-NiFh1 & 0.1001 & 0.0041 & 3.666 & 3.669 & 0.000 & 6.847 & 99.8 & 0.0022 & 74.97 & 2.2 & $\mathrm{Ni}+\mathrm{Fh}+\mathrm{G}$ & 0.1440 \\
\hline $\mathrm{C}-\mathrm{NiFh} 2$ & 0.1001 & 0.0040 & 3.666 & 3.669 & 0.000 & 6.279 & 99.8 & 0.0012 & 40.89 & 1.3 & $\mathrm{Ni}+\mathrm{Fh}+\mathrm{G}$ & 0.1433 \\
\hline C-NiFh3 & 0.1001 & - & 3.666 & 3.668 & 0.000 & 8.665 & 99.8 & 0.0010 & 34.08 & 1.2 & $\mathrm{Ni}+\mathrm{Fh}$ & N/A \\
\hline C-NiFh4 & 0.1000 & - & 3.666 & 3.667 & 0.000 & 5.856 & 99.8 & 0.0011 & 37.48 & 1.2 & $\mathrm{Ni}+\mathrm{Fh}$ & N/A \\
\hline NiBF1 & 0.0355 & - & 5.299 & 1.881 & 0.000 & 61.090 & 96.8 & 0.0075 & 255.6 & 16.8 & $\mathrm{Ni}+\mathrm{BF}$ & 0.1792 \\
\hline NiBF2 & 0.0354 & - & 5.299 & 1.877 & 0.000 & 66.660 & 96.4 & 0.0072 & 245.3 & 16.6 & $\mathrm{Ni}+\mathrm{BF}$ & 0.1792 \\
\hline $\mathrm{C}-\mathrm{NiBF} 1$ & 0.0355 & - & 5.299 & 1.883 & 0.000 & 19.771 & 98.9 & 0.0009 & 30.67 & 2.7 & $\mathrm{Ni}+\mathrm{BF}$ & 0.1792 \\
\hline $\mathrm{C}-\mathrm{NiBF} 2$ & 0.0352 & - & 5.299 & 1.866 & 0.000 & 20.701 & 98.9 & 0.0037 & 126.1 & 7.9 & $\mathrm{Ni}+\mathrm{BF}$ & 0.1792 \\
\hline
\end{tabular}


Table 3.

\begin{tabular}{|c|c|c|c|c|c|c|c|c|c|c|c|}
\hline $\begin{array}{c}\mathrm{N}_{\mathrm{O}} \\
\mathrm{R}(\mathrm{Ni}- \\
\left.\mathrm{O}_{1}\right) \\
2 \sigma^{2} \\
\theta, \varphi\end{array}$ & $\begin{array}{c}\mathrm{N}_{\mathrm{O}} \\
\mathrm{R}(\mathrm{Ni}- \\
\left.\mathrm{O}_{2}\right) \\
2 \sigma^{2} \\
\theta, \varphi \\
\end{array}$ & $\begin{array}{c}\mathrm{N}_{\mathrm{O}} \\
\mathrm{R}(\mathrm{Ni}- \\
\left.\mathrm{O}_{3}\right) \\
2 \sigma^{2} \\
\theta, \varphi \\
\end{array}$ & $\begin{array}{c}\mathrm{N}_{\mathrm{O}} \\
\mathrm{R}(\mathrm{Ni}- \\
\left.\mathrm{O}_{4}\right) \\
2 \sigma^{2} \\
\theta, \varphi\end{array}$ & $\begin{array}{c}\mathrm{N}_{\mathrm{O}} \\
\mathrm{R}\left(\mathrm{Ni}^{-\mathrm{O}_{5}}\right) \\
2 \sigma^{2} \\
\theta, \varphi\end{array}$ & $\begin{array}{c}\mathrm{N}_{\mathrm{O}} \\
\mathrm{R}\left(\mathrm{Ni}^{-\mathrm{O}_{6}}\right) \\
2 \sigma^{2} \\
\theta, \varphi\end{array}$ & $\begin{array}{c}\mathrm{N}_{\mathrm{Fe}} \\
\mathrm{R}\left(\mathrm{Ni}^{-\mathrm{Fe}_{1}}\right) \\
2 \sigma^{2} \\
\theta, \varphi\end{array}$ & $\begin{array}{c}\mathrm{N}_{\mathrm{Fe}} \\
\mathrm{R}\left(\mathrm{Ni}^{-\mathrm{Fe}_{2}}\right) \\
2 \sigma^{2} \\
\theta, \varphi\end{array}$ & $\mathrm{EF}$ & $\begin{array}{c}\mathrm{R} \\
(\%)\end{array}$ & 苨 & 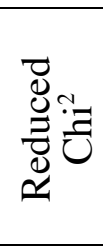 \\
\hline 1.0 & 1.0 & 1.0 & 1.0 & 1.0 & 1.0 & 1.0 & 1.0 & \multirow{4}{*}{3.73} & \multirow{4}{*}{32.8} & \multirow{4}{*}{1.06} & \multirow{4}{*}{39} \\
\hline 2.07 & 2.00 & 2.09 & 2.05 & 2.08 & 2.04 & 3.01 & 3.15 & & & & \\
\hline 0.009 & 0.009 & 0.009 & 0.009 & 0.009 & 0.009 & 0.010 & 0.006 & & & & \\
\hline 90,0 & 90,90 & 90,180 & 90,270 & 0,0 & 180,0 & 55,100 & 55,170 & & & & \\
\hline
\end{tabular}


Figure 1.
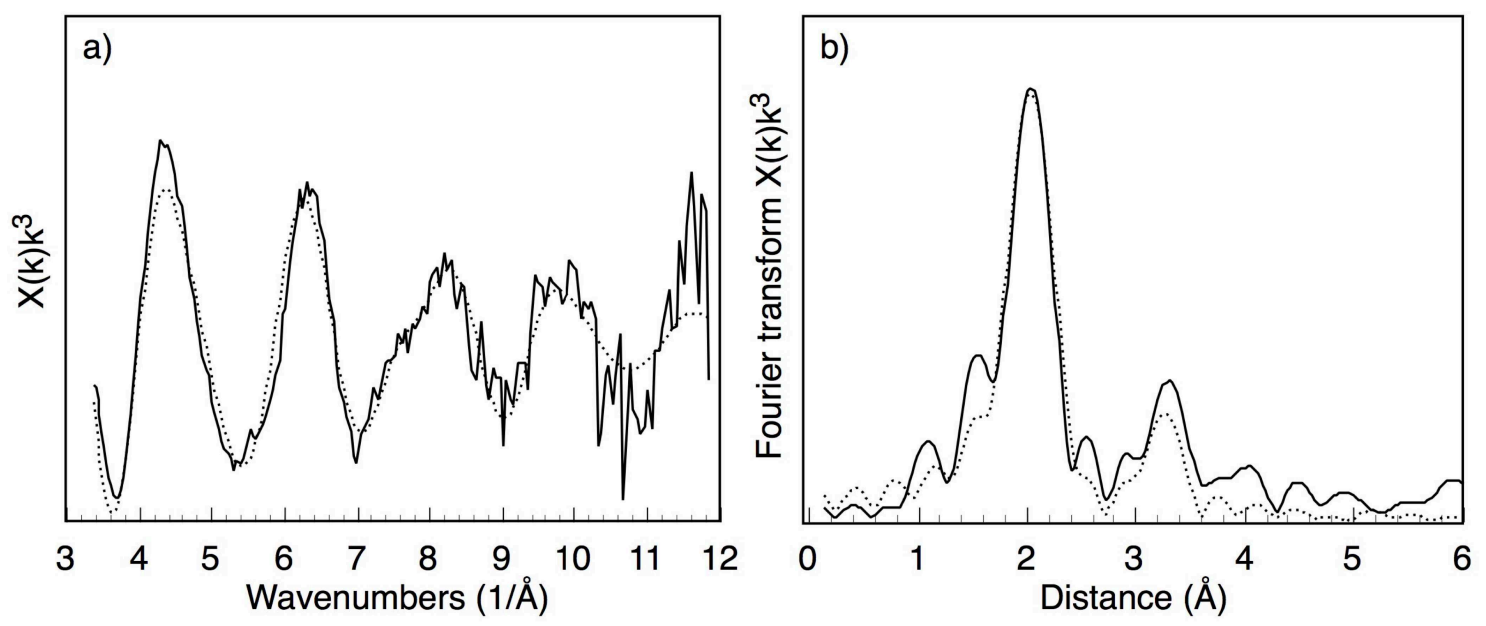

c)

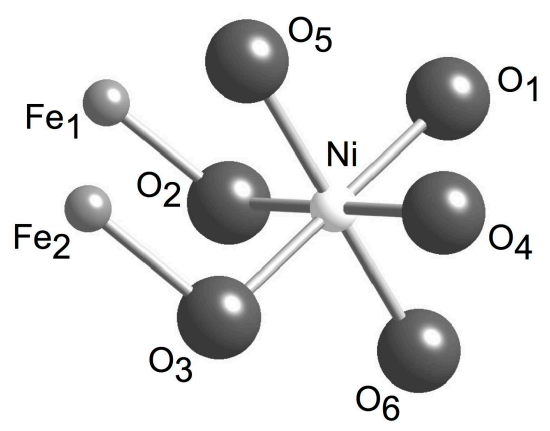


Figure 2.

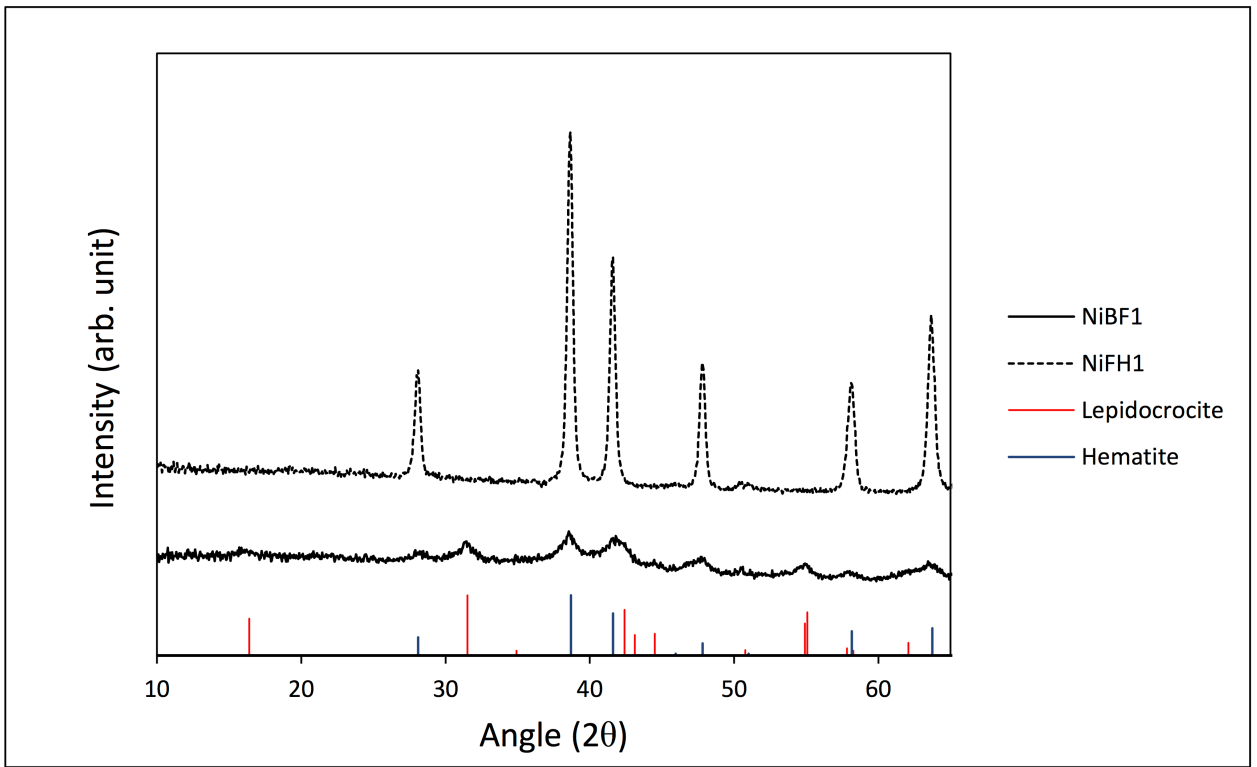


Figure 3.

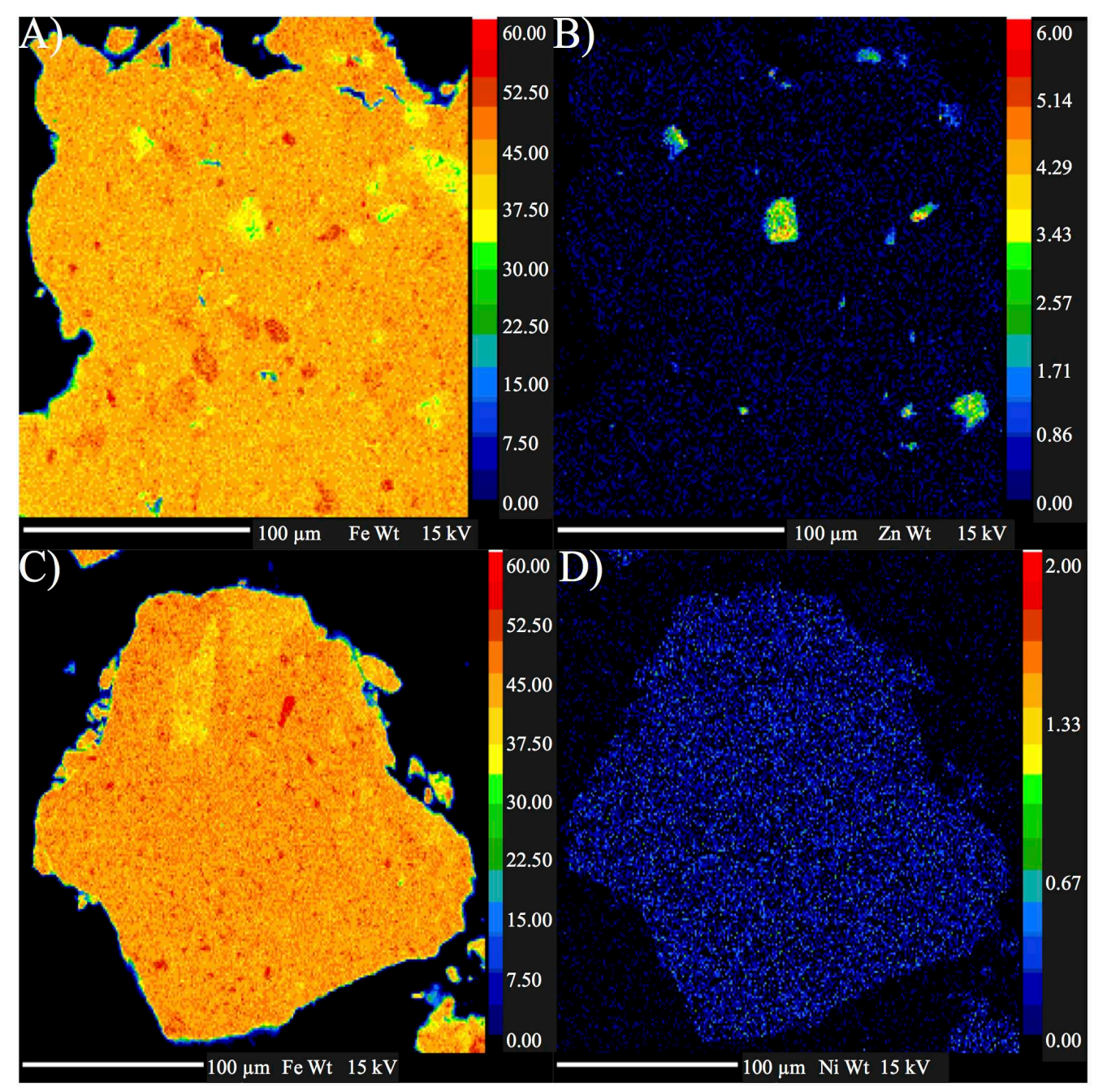


Figure 4.

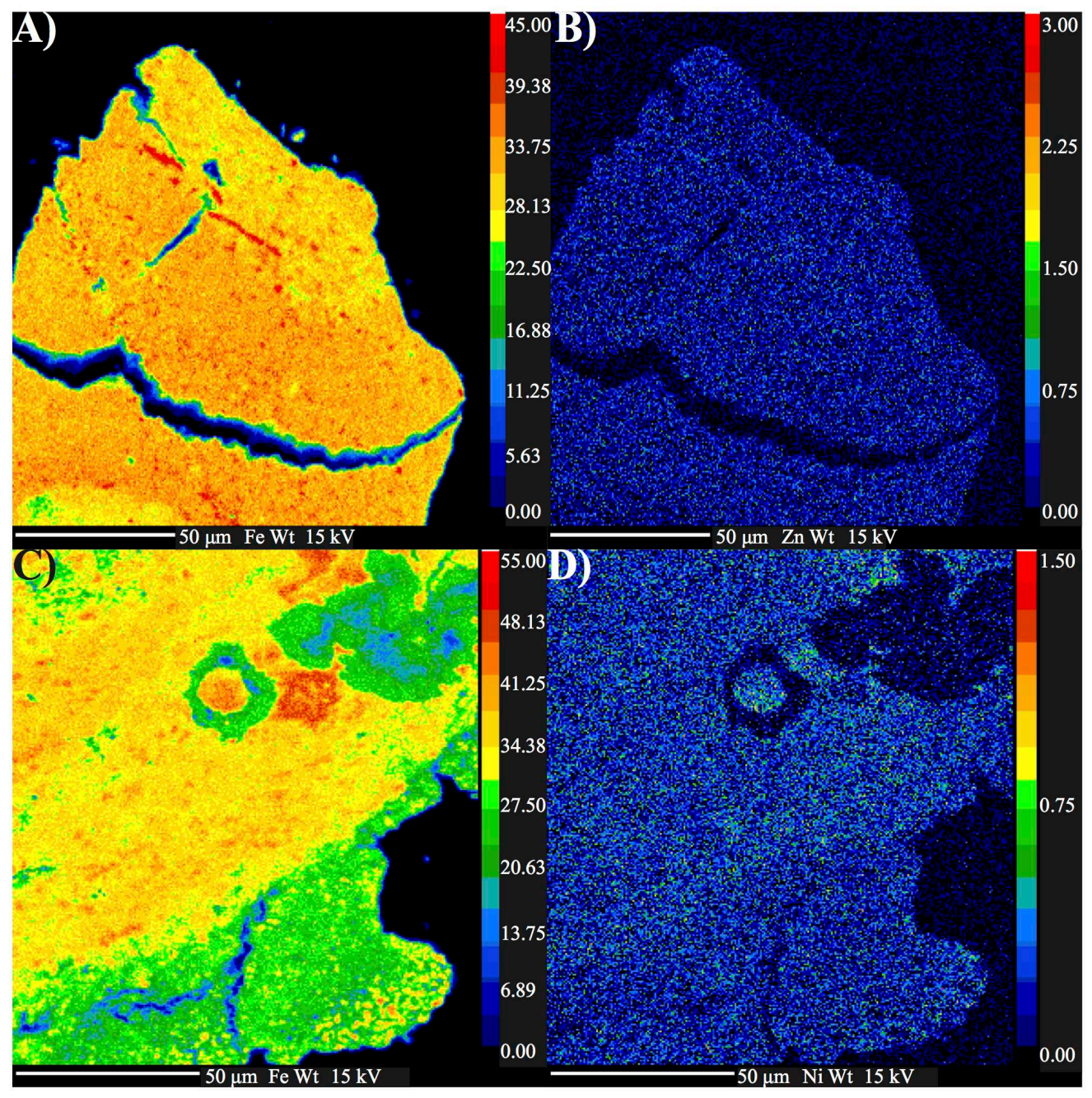

